\title{
Career Fire Lieutenant Dies in Cluttered Apartment Fire on 19th Floor of High-rise Residential Apartment Building - New York
}

\section{Executive Summary}

On July 05, 2014, a 40-year-old male career lieutenant was overcome by extreme fire conditions while attempting to find the seat of the fire.

The fire was located in the bedroom of a 500square-foot apartment on the $19^{\text {th }}$ floor of a 21-story residential apartment building. The apartment was extremely cluttered with personal possessions stacked high against all walls, making travel through the apartment difficult. The lieutenant and his Ladder 119 crew forced the door to the fire apartment and entered to search for the seat of the fire. The Engine 211 lieutenant and fire fighter followed them into the apartment with a charged hoseline.

Due to the cluttered conditions, which limited

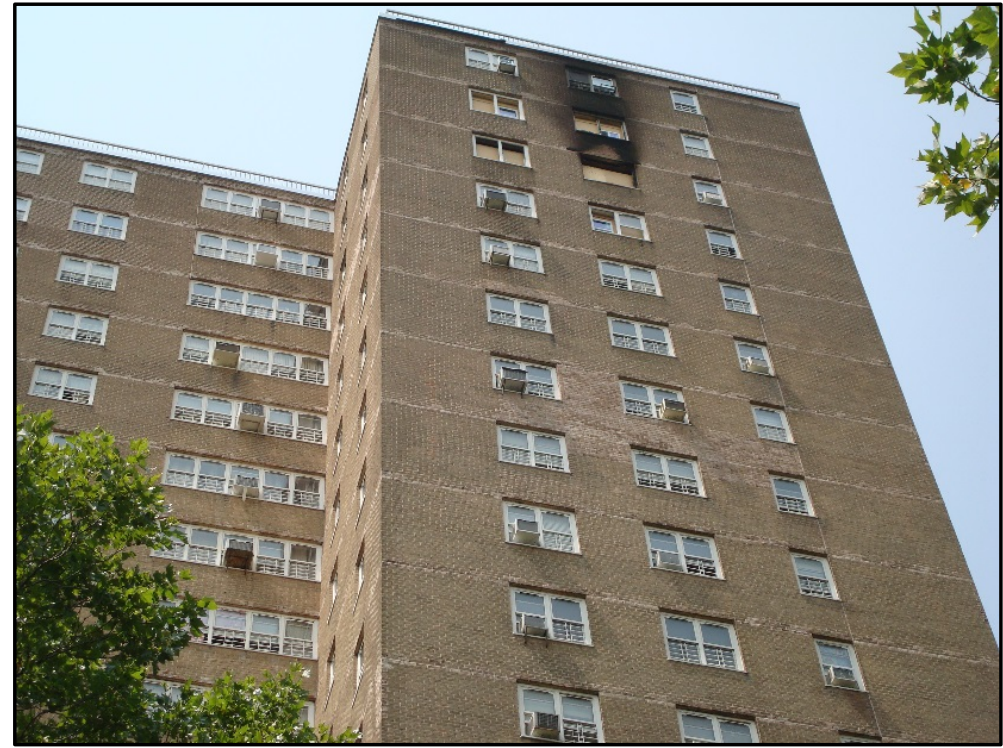

View of apartment building looking up from street level. Center window is room of origin. (NIOSH photo) their mobility, crews had trouble locating the seat of the fire. Visibility was limited due to the thick, optically-dense smoke. The conditions inside the apartment rapidly deteriorated, forcing both crews to withdraw to the hallway. The Engine 211 lieutenant radioed a Mayday and stated he had fire behind him. All fire fighters in the apartment were able to withdraw except for the Ladder 119 lieutenant. Engine 211 re-entered the apartment and extinguished the fire. A fire fighter reported hearing a PASS device in the direction of the bedroom. The Ladder 119 lieutenant was found a short time later, unresponsive and with his facepiece dislodged from his face. He was immediately transported to a local hospital where he was pronounced dead.

\section{Contributing Factors}

- Cluttered conditions within apartment blocked ingress and delayed getting water on the fire

- Fire originated in bedroom where an extension cord overheated under clutter

- Thick, dense smoke limited visibility

- Thick, dense smoke became fuel in rapid fire progression

- Lack of water on the fire

- Lack of crew integrity exiting the apartment 


\section{Career Fire Lieutenant Dies in Cluttered Apartment Fire on $19^{\text {th }}$ Floor of High-rise Residential Apartment Building - New York}

- Lack of a sprinkler system in high-rise apartment building

- Radio traffic including Maydays not heard by everyone on fireground

- Defective elevators in high-rise apartment building.

\section{Key Recommendations}

- Fire departments should integrate current findings of fire behavior research conducted by the National Institute of Standards and Technology (NIST) and Underwriter's Laboratories (UL) into operational procedures by developing standard operating procedures, conducting live fire training, and revising fireground tactics

- Fire departments should have a written risk management plan, use risk management principles at all structure fires and especially at incidents involving high risk hazards

- Fire departments should ensure that crew integrity is properly maintained by voice or radio contact when operating in an immediately dangerous to life and health (IDLH) atmosphere

- Fire departments should ensure that all fire fighters are trained on the unique hazards presented by hoarding and standard operating procedures are developed and enforced to provide guidance for fire fighters confronted with hoarding conditions

- Fire departments should ensure that fire fighters are properly trained in air management

- Fire departments should ensure fire fighters are trained in self-contained breathing apparatus (SCBA) emergencies

- Fire departments should ensure that existing standard operating procedures for high-rise firefighting operations are reviewed, revised as necessary, and implemented.

Additionally,

- $\quad$ Municipalities, building owners, and authorities having jurisdiction should consider requiring sprinkler systems to be installed in multi-family and residential mixed occupancy structures.

The National Institute for Occupational Safety and Health (NIOSH), an institute within the Centers for Disease Control and Prevention (CDC), is the federal agency responsible for conducting research and making recommendations for the prevention of work-related injury and illness. In 1998, Congress appropriated funds for NIOSH to conduct a fire fighter initiative that resulted in the NIOSH "Fire Fighter Fatality Investigation and Prevention Program" which examines line-of-duty-deaths or on duty deaths of fire fighters to assist fire departments, fire fighters, the fire service and others to prevent similar fire fighter deaths in the future. The agency does not enforce compliance with State or Federal occupational safety and health standards and does not determine fault or assign blame. Participation of fire departments and individuals in NIOSH investigations is voluntary. Under its program, NIOSH investigators interview persons with knowledge of the incident who agree to be interviewed and review available records to develop a description of the conditions and circumstances leading to the death(s). Interviewees are not asked to sign swom statements and interviews are not recorded. The agency's reports do not name the victim, the fire department or those interviewed. The NIOSH report's summary of the conditions and circumstances surrounding the fatality is intended to provide context to the agency's recommendations and is not intended to be definitive for purposes of determining any claim or benefit.

For further information, visit the program website at www.cdc.gov/niosh/fire or call toll free 1-800-CDC-INFO (1-800-232-4636). 


\section{Death in the line of duty...}

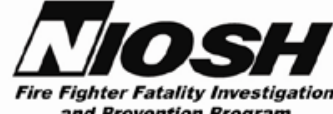

and Prevention Program

A summary of a NIOSH fire fighter fatality investigation

July 7,2016

\section{Career Fire Lieutenant Dies in Cluttered Apartment Fire on $19^{\text {th }}$ Floor of High-rise Residential Apartment Building - New York}

\section{Introduction}

On July 05, 2014, a 40-year-old male career fire lieutenant died after he was overcome by extreme fire conditions while attempting to find the seat of the fire in an extremely cluttered 500 square-foot apartment. The fire apartment was located on the 19th floor of a 21-story residential apartment building.

On July 7, 2014, the U.S. Fire Administration notified the National Institute for Occupational Safety and Health (NIOSH) of this incident. On July 21, 2014, a safety engineer and an investigator from the NIOSH Fire Fighter Fatality Investigation and Prevention Program traveled to New York to investigate this incident. The NIOSH investigators met with officials of the fire department and with representatives from the Uniformed Firefighters Association. The NIOSH investigators also met with representatives of the Uniformed Fire Officers Association. Both are affiliated with the International Association of Fire Fighters. The NIOSH investigators reviewed witness statements of fire fighters and officers involved in the incident, examined photographs and video of the fireground, and reviewed the lieutenant's training records and death certificate. The NIOSH investigators also reviewed the department's fireground standard operating procedures and listened to the dispatch tapes of this incident. The NIOSH investigators visited and photographed the incident site, the fire department's training facility, the fire department's air mask maintenance shop, and the communications center.

\section{Fire Department}

This career fire department is the largest municipal fire department in the United States and the second largest in the world. The fire department employs approximately 10,200 uniformed fire fighters and over 3,600 uniformed emergency medical technicians (EMTs) and paramedics. The fire department provides fire protection; technical rescue; primary response to biological, chemical and radioactive hazards; and emergency medical services.

Based upon 2010 census information, the fire department serves a population of 8.19 million persons in an area of approximately 321.8 square miles. The city is made of five boroughs, each of which is a county. On January 1, 1898, a number of disparate fire services were consolidated under the unified command of the first fire commissioner. The fire department opened its present-day Fire Academy in 1975, and its Fire Marshal Training Center in 1994 and assumed command and control of its EMS Academy in 1996 [FD website 2015 http://www.nyc.gov/html/fdny/html/stats/citywide.shtml].

The fire department faces highly multifaceted firefighting challenges, some of which are unique to the city. The fire department has emergency response jurisdiction to respond to building types that range from wood-frame single-family homes to high-rise structures. The city has many secluded bridges and tunnels, as well as large parks and wooded areas that can give rise to brush fires. The city is also home to ports, two international airports, railroads and one of the largest subway systems in the world, consisting of hundreds of miles of tunnels with electrified tracks. 


\section{Career Fire Lieutenant Dies in Cluttered Apartment Fire on 19th Floor of High-rise Residential Building - New York}

Operationally and geographically, the department is nominally organized, into five Borough Commands. Within those five Borough Commands exist nine firefighting divisions, each headed by a deputy division chief. Within each division are four to seven battalions, each led by a battalion chief. Each battalion consists of three to eight firehouses of approximately 180-200 firefighters and officers. Each firehouse consists of one to three fire companies. Each fire company is led by a captain, who commands three lieutenants and 15 to 25 firefighters. Each company has four shifts of fire fighters. Tours can be either night tours (6 p.m. to 9 a.m.) or day tours ( 9 a.m. to 6 p.m.). In one tour or shift, each company is commanded by a lieutenant or the captain and is made up of four to five fire fighters, depending on the type of fire company/unit: an engine company is staffed by an officer and four to five firefighters; a ladder company is staffed by an officer and five firefighters; a rescue company is staffed by an officer and five firefighters; a squad company is staffed by an officer and five firefighters; a marine company is staffed by an officer and four firefighters; the hazardous materials (hazmat) company is staffed by an officer and six firefighters [FD website 2015].

The fire department has written policies and procedures, which are available to all department members within their stations and cover a broad range of topics. These policies and procedures have been implemented and are enforced.

\section{Engine Companies}

Department engine companies are tasked with securing a water supply from a fire hydrant, then extinguishing a fire. The apparatus of an engine is known as a pumper truck and carries a pump (usually 1,000-2,000 gallons per minute), a water tank (usually 500 gallons), fire hoses of varying diameters (usually $1 \frac{3 / 4}{4}$ inch, $2 \frac{1}{2}$ inch, $3 \frac{1}{2} 2$ inch and 5 inch) in 50 foot lengths, emergency medical supplies, ground extension ladders, and an assortment of tools.

Engine companies are staffed with an officer and four to five fire fighters. Engine company members are designated for job assignments as follows:

Officer

Engine company chauffer (ECC)

Nozzle - operates nozzle for fire attack

Backup - assists nozzle with hoseline placement

Control - hooks up hose to standpipe at high-rise events, controls hoseline stretch

Doorman - assists in stretch (if the engine company has 5-person crew).

\section{Ladder Companies}

Department ladder companies (also known as truck companies) are tasked with search and rescue, forcible entry, and ventilation at the scene of a fire. A ladder company can operate three types of ladder trucks: an aerial ladder truck, equipped with a 100-foot aerial ladder mounted at the rear of the apparatus; a tower ladder truck, equipped with either a 75-foot or 95-foot telescoping boom and bucket mounted in the center of the apparatus; a tractor-drawn aerial ladder truck, or tiller/tractor trailer, equipped with a 100-foot aerial ladder. A ladder company carries various forcible entry, ventilation, 


\section{Career Fire Lieutenant Dies in Cluttered Apartment Fire on 19th Floor of High-rise Residential Building - New York}

and rescue tools to deal with an assortment of fires and emergencies, including motor vehicle incidents.

Ladder companies are staffed with an officer and five fire fighters. Ladder company members are designated for job assignments as:

Officer

Ladder company chauffer (LCC)

Roof - goes to roof or floor above fire

Outside vent - goes to rear of structure: in high-rise operations, controls the elevator Irons - carries forcible entry tools

Can - carries water can for fire extinguishment

\section{Rescue Companies}

Department rescue companies are composed of elite, highly and specially trained, most experienced members of the department. A rescue company is tasked with responding to and dealing with specialized fire and rescue incidents (both civilian and fire fighter) that are beyond the scope and duties of a standard engine or ladder company. Rescue companies operate rescue trucks, commonly known as "tool boxes on wheels," which carry a wide variety of specialized tools and equipment to aide in operations at technical rescues, collapse/confined space rescues, water/dive rescues, and highangle/below-grade rescues. They respond to all fires within their response district.

\section{Squad Companies}

Squad companies are also composed of specially trained fire fighters from the department. Squad companies were initially established by the department to serve as "manpower companies" to supplement the manpower and operations of engine and ladder companies. Today, squad companies can function as either engine or ladder companies at the scene of a fire, but are also equipped with similar equipment and specialized tools as the rescue company. In particular, members of a squad company are highly trained in mitigating hazardous materials (hazmat) incidents, supplementing the department's single hazmat Company. Squad companies also operate a small step van as a second piece of apparatus in response to hazmat incidents.

\section{Marine Companies}

The department's marine companies operate the department's fireboats and are tasked with SCUBA/dive rescue and off-land firefighting in the city's rivers and harbors. The department's three marine companies operate large fireboats and smaller, secondary rescue boats to respond to various marine-related emergencies. The department operates three Class I fireboats as marine companies. 


\section{Career Fire Lieutenant Dies in Cluttered Apartment Fire on 19th Floor of High-rise Residential Building - New York}

\section{Hazardous Materials Company}

The department's hazardous materials (hazmat) company, responds to all major city-wide hazardous materials incidents, building collapses, contamination-related incidents, terrorism-related disasters, major emergencies, and a variety of other incidents in which their services may be needed. Like the rescue and squad companies, members of Hazmat Company 1 are experienced and specially trained to deal with hazardous situations. The hazmat company operates a hazmat truck, similar to a rescue truck, which carries a variety of equipment to deal with hazardous situations. Hazmat 1 also operates a smaller rescue truck which carries extra equipment not carried on the company's main piece of apparatus. The hazmat company is primarily supplemented by the squad companies, the rescue companies, and a handful of engine companies whose members are certified hazmat technicians. These engine companies, like the squad companies, also operate smaller step vans that carry hazmat equipment [FD website 2015].

\section{Training and Experience}

The state of New York requires that fire departments train career fire fighters to a level equivalent to National Fire Protection Association (NFPA) 1001 Standard for Fire Fighter Professional Qualifications [NFPA 2013a]. The state also requires 100 hours of annual in-service training.

The fire department operates and maintains its own fire training academy. Recruits are selected from a civil service examination list maintained by the city. The fire department requires all fire fighters to complete an 18-week training program at the department's fire academy. Fire fighter recruits are instructed in the basics of fire suppression systems and firefighting tactics. After graduating from the fire academy, the recruits go through a 1-year probationary period working as part of a company. Note: When the lieutenant graduated from the academy, the program consisted of 13 weeks of training. At the completion of recruit school, the fire fighter recruit receives the following certifications:

- $\quad$ NFPA 1001, Standard for Fire Fighter Professional Qualifications; Fire Fighter I and Fire Fighter II

- HazMat Awareness

- HazMat Operations

- Certified First Responder - Defibrillator (CFR-D).

After the completion of recruit school, the recruit fire fighter becomes a probationary fire fighter and is assigned to an engine company or ladder company. The probationary fire fighter is evaluated by the officer at 3, 5, 8, 11, and 17 months. The probationary period is 18 months.

In-service training for fire department members consists of the following:

- Company-level training

- Fire Academy - All companies attend training at the Fire Academy at least twice a month. As many as 60 companies per day go out of service and report to the academy for training.

- KIOSK training: The fire department operates a number of websites and on-line training materials devoted to member training, safety, and preparedness. This training process is designed to assist with keeping members informed of the latest tactics and information from 


\section{Career Fire Lieutenant Dies in Cluttered Apartment Fire on 19th Floor of High-rise Residential Building - New York}

department and fire service subject matter experts. Members are required to complete 1 hour of training per each tour worked (day and night tours).

All training at the Fire Academy is tracked electronically so that the training division staff can identify fire fighters who are not getting adequate training. All instructors at the Fire Academy are New Yorkstate certified fire instructors.

All new company officers receive both company officer level training and certified instructor training at the Fire Academy. This company officer development training includes:

Lieutenant

- 1st Line Supervisor School - 6 weeks (mandated by state of New York)

- NFPA 1041, Standard for Fire Service Instructor Professional Qualifications, Instructor I

- Participate in "Mother of All Drills" (MOAD).

Captain

- 6 weeks of Officer In-Service Training

- MOAD Drills

- Focus on Personnel Management

Battalion Chief

- 7 weeks of Officer In-Service Training

- Incident Command System (ICS) Training.

- High-Rise

- HazMat

Deputy Chief

- 2 weeks of Officer In-Service Training

- ICS Training.

- Forecasting how incidents will look after 30 minutes

- Span of control

Specialized training is also provided for positional needs such as a 2-week training class for driver / chauffer positions that includes simulator driving, hands-on driving and pump operations. Chief's aides also receive specialized training on an as-needed basis.

The lieutenant in this incident had 14 years of experience as a fire fighter and had been a lieutenant for approximately 1 year. 
Career Fire Lieutenant Dies in Cluttered Apartment Fire on 19th Floor of High-rise Residential Building - New York

\section{Equipment and Personnel}

This high rise fire incident involved a full box alarm assignment on July 5, 2014, at 2110 hours. The following apparatus and personnel were dispatched:

Engine 211 (E211)

Lieutenant (E211 Lt)

Chauffer (E211 ECC)

3 fire fighters (E211 Nozzle, E211 Backup, and E211 Control)

Ladder 119 (L119)

Lieutenant (L119 Lt - the victim)

Chauffer (L119 LCC)

4 fire fighters (L119 Roof, L119 Outside Vent, L119 Irons, L119 Can

Engine 221 (E221)

Lieutenant (E221 Lt)

Chauffer (E221 ECC)

3 fire fighters (E221 Nozzle, E221 Backup, and E221 Control)

Ladder 104 (L104)

Lieutenant (L104 Lt)

Chauffer (L104 LCC)

4 fire fighters (L104 Roof, L104 Outside Vent, L104 Irons, L104 Can)

Engine 216 (E216)

Lieutenant (E216 Lt - on detail from Ladder 106)

Chauffer (E216 ECC)

3 fire fighters (E216 Nozzle, E216 Backup, and E216 Control)

Battalion Chief 35 (BC35) and Chief’s Aide

\section{Timeline}

An approximate timeline summarizing the sentinel events in this incident up to the time of the Mayday is listed below. The times are approximate and were obtained by studying the available dispatch channel records, witness statements, run sheets and fire department records. This timeline is not intended, nor should it be used, as a formal record of events. Only those dispatch channel communications directly related to the fatal incident are included.

NOTE: The fire department uses a "Handie Talkie Recorder System" set up in every Battalion car to capture fireground radio transmissions made at the scene. The quality of these transmissions is dependent on many factors such as the location of the Battalion car, radio frequency dynamics, the type of building construction and configuration. Due to these factors, each recorder may capture clearer and in some cases different transmissions. For example, the recorder from Battalion 35 positioned closest to the command post did not capture the first MAYDAY transmission whereas it was 
Career Fire Lieutenant Dies in Cluttered Apartment Fire on 19th Floor of High-rise Residential Building - New York

recorded by Battalion 31 and 57. Furthermore, these recorders captured transmissions that may not have been received by Commanders and Firefighters on the fireground. This report is a compilation of all Battalion Recorders at the scene. Recordings were analyzed by the department at different speeds to clarify what was being transmitted. Listening to audio in a quiet, sterile environment differs greatly from the ambient noise that occurs at fire operations.

- 21:10:05 Hours

Dispatch Center received a phone call reporting the smell of smoke in a high-rise apartment building.

Engine 211 (E211), Ladder 119 (L119), Engine 221 (E221), Ladder 104 (L104), Engine 216

(E216), Battalion 35 (BC35) were dispatched.

- 21:12:48 - 21:12:53 Hours

E211 and L119 on-scene

- 21:13:48 Hours

L119 lieutenant (the victim) radioed - 10-77; "Visible fire from the upper floors"

- 21:14:00 Hours (approximate)

Engine 252, Engine 210 (designated as the High-rise Nozzle Engine), Engine 230 (designated CFRD Engine), Ladder 110 (designated FAST Truck), Battalion 31, Battalion 57, Battalion 37 (designated as Safety Officer), Division 11, RS 02, SB01, FC01, RB 01, Ladder 105 (designated for Ventilation Support) were added to the dispatch.

- $2114-2115$ Hours

E221, L104, E216 - on scene

Battalion 35 on scene and assumed incident command

- 2116 Hours

L102: 3rd due Ladder - on scene

- 2120 Hours

L110: FAST - on scene

Division 11 arrived on-scene and assumed incident command

- 2122 Hours (approximate)

L119 crews enter the apartment with E211at apartment entrance

E230: CFR-D - on scene

- 2128 Hours

First Maydays by both L119 and E211 lieutenants (L-119 was not heard by most everyone on fireground)

E211 Lt reports "Fire is behind us" and confirms "hoseline is not in operation" 
Career Fire Lieutenant Dies in Cluttered Apartment Fire on 19th Floor of High-rise Residential Building - New York

- 2129 Hours

L119 Lt - “Mayday, Mayday, Mayday” (not heard by most everyone on fireground)

- 2130 Hours

2nd Alarm transmitted for Box 316

- 2135 Hours (approximate)

L119 lieutenant located in the bedroom at the foot of the bed

Other companies assigned to on the first alarm included:

- $\quad$ Rescue 2

- $\quad$ Squad 252

- BC31 (SAE)

- Division 11 - Incident Commander

- Safety Battalion

- Rescue Battalion

- Ladder 105 - Ventilation

- Field Communication Unit

- Engine 210 - HRN

- Command Tac

- Battalion 57 (Fire Floor)

- Battalion 37 (Safety)

- Emergency Medical Services

32V3 Basic life support ambulance (BLS)

35C1 Advanced Life Support ambulance (ALS)

\section{Personal Protective Equipment}

At the time of the incident, the lieutenant was wearing his full array of firefighting turnout gear including bunker pants, bunker coat, self-contained breathing apparatus (SCBA) with integrated PASS device, fire resistant hood, helmet, gloves and boots. The lieutenant was carrying a fire-departmentissued radio, and a thermal imaging camera and had a personal light attached to his bunker coat.

The self-contained breathing apparatus (SCBA) worn and used by the deceased lieutenant was shipped to the NIOSH National Personal Protection Technology Laboratory for additional evaluation and testing. The SCBA exhibited some heat damage and other signs of general wear. The remote pressure gauge was damaged by heat exposure and was unreadable. The cylinder was determined to be empty by the fire department. The integrated personal alert safety system (PASS) device was activated and functioned normally. The SCBA was tested using a replacement cylinder and facepiece supplied by the fire department. The SCBA met the minimum requirements in six of seven tests conducted by 


\section{Career Fire Lieutenant Dies in Cluttered Apartment Fire on 19th Floor of High-rise Residential Building - New York}

NIOSH NPPTL. During the remaining service life indicator (low-air alarm) test, the alarm sounded intermittently during the test indicating an issue with the pressure reducer. See Appendix One for more details and test results. The complete NIOSH NPPTL evaluation report is available upon request.

\section{Weather and Road Conditions}

At the time of this incident, the weather was clear with an approximate temperature of 76 degrees Fahrenheit and the relative humidity was approximately 37 percent [Weather Underground 2014]. Variable winds were measured at 4.6 miles per hour. The incident occurred on the $19^{\text {th }}$ floor of a 21story residential apartment building. The weather conditions were not considered to be a factor in this incident.

\section{Structure}

This incident occurred in a 21-story high-rise multi-family apartment building that was one of many high-rise apartment buildings and multi-purpose buildings located in a densely populated part of the city. The building was fireproof in construction. See Diagram 1 for an indication of the building's location and orientation. The building had two elevators located in the main lobby that serviced every floor. Each floor was also serviced by two isolated stairwells, commonly referred to as scissor stairs. Scissor stairs are two enclosed stairs separated by code-rated walls contained within a single stairway shaft. Per city building codes, scissor stairs may be installed in multi-family dwellings rather than requiring stairs to be remote, and are counted as two separate exits. Scissor stair exit doors are placed no less than 15 feet apart in the public hallway. Note: Many of the high-rise apartment buildings in this community were operated by the city's public housing authority.

\section{Investigation}

On July 5, 2014, a 40-year-old male career fire lieutenant died from injuries received when he became trapped while searching for the seat of the fire burning in a 500 square-foot apartment on the $19^{\text {th }}$ floor of a high-rise residential apartment building.

At 2110 hours, the fire department was dispatched for the report of the smell of smoke in a 21-story high-rise residential apartment building. Engine 211 (E211), Ladder 119 (L119), Engine 221 (E221), Ladder 104 (L104) and Engine 216 (E216) along with Battalion Chief 35 (BC35) were dispatched. Engine 211 and Ladder 119 were the first companies on scene at 2112 hours. The E211 crew got off the engine, then the chauffer moved Engine 211 west to the hydrant at the next corner (see Diagram 1), connected to the hydrant using a 10-foot section of soft suction, and then began to set up to supply the building standpipe. He stretched out three lengths of 31/2-inch supply line to the standpipe siamese connection on Side Alpha of the building.

As the crews walked through the courtyard to the lobby entrance, they looked up and observed fire in a window (see Photo 1 and Photo 2). The fire was not lapping out but it appeared like the window frame was on fire. Battalion Chief 35 arrived on scene and assumed incident command. BC35 radioed the dispatcher to confirm a working fire was in progress. 


\section{Career Fire Lieutenant Dies in Cluttered Apartment Fire on 19th Floor of High-rise Residential Building - New York}

The high-rise apartment building contained two elevators with fireman controls and two separate stairways (scissor stairs) contained within separate stairwells. The elevator on the left was pre-set to operate in "sabbatical mode," meaning the elevator was pre-programed to stop on every other floor as it rose up and down so that residents did not have to manually operate the elevator. At 2115 hours, the Ladder 119 outside vent man (OV) radioed that he had control of one elevator. The elevator on the left improperly and unexpectedly did not respond to fireman mode and operated erratically throughout the operation. It was not used for firefighting purposes. The elevator on the right was used for firefighting purposed and also operated erratically.

The Ladder 119 crew (lieutenant and three fire fighters) entered the elevator and rode up to the $17^{\text {th }}$ floor. The L119 OV told the E211 crew he would be right back down for them. At approximately 2116 hours, the L119 lieutenant advised the Engine 211 lieutenant to use the A-stairwell as the attack stairwell. The E211 lieutenant immediately acknowledged that the A-stairwell would be the attack stairwell. A resident living on the $19^{\text {th }}$ floor told the L119 crew that she thought the fire was in apartment 19B. Note: The A and B-stairwell designations refer to the two enclosed stairs located within a single stairway shaft. The A and B designations do not correspond to Side Alpha and Side Bravo of this building.

When the elevator car returned to the lobby, the E211 crew (lieutenant and three fire fighters) took the elevator to the 17th floor. The E211 lieutenant located the A stairway and the crew advanced to the 19th floor. The Ladder 119 lieutenant and two fire fighters (Can and Irons) were forcing the door to apartment 19B. The hallway on the 19th floor was clear and no smoke was present at this time. The E211 lieutenant yelled down the stairs to the E211 crew and told them that the standpipe outlet was in the hallway and told the E211 Nozzle to flake the hose up the stairs. The E211 lieutenant directed the E211 Nozzle to stretch their line to the apartment door.

The L119 roof man went to the $20^{\text {th }}$ floor and checked apartment $20 \mathrm{~B}$ for fire extension. He radioed the L119 lieutenant and advised the L119 lieutenant of the apartment layout. The L119 lieutenant acknowledged the report from the L119 roof man and soon after radioed to Command that L119 was forcing the door to apartment 19B. Battalion Chief 31 was the second-due battalion chief. He arrived on scene and reported to the incident commander BC35. BC31 was assigned as the attack chief by the incident commander. Note: The National Incident Management System (NIMS) designation for BC31 would be Division 19. They listened to the radio report from the L119 lieutenant that the L119 inside crew was at the apartment door and waiting on water. 
Career Fire Lieutenant Dies in Cluttered Apartment Fire on 19th Floor of High-rise Residential Building - New York

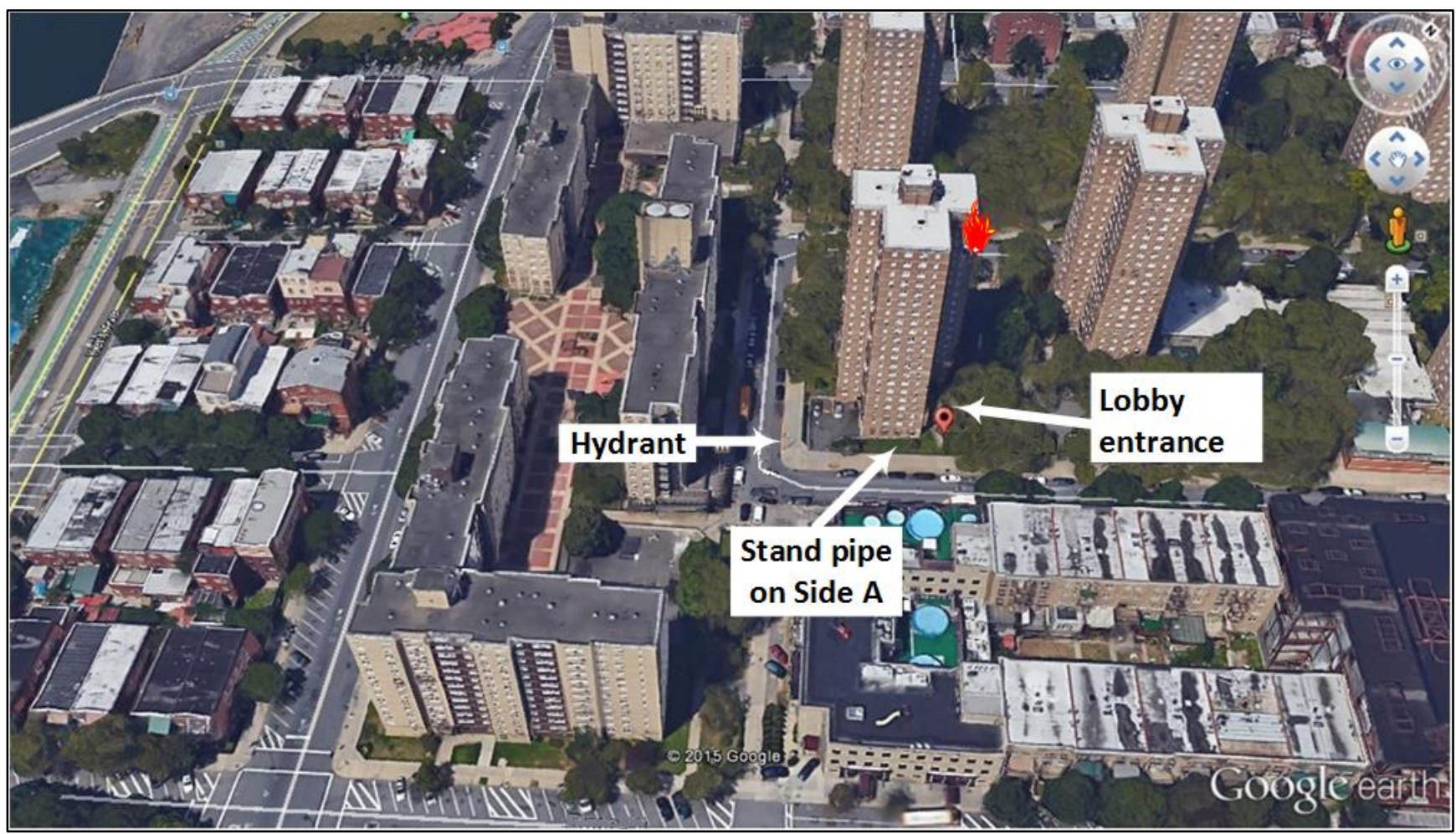

Diagram 1. Overhead view of incident location. (NIOSH diagram adapted from Google Earth.) 


\section{Career Fire Lieutenant Dies in Cluttered Apartment Fire on 19th Floor of High-rise Residential Building - New York}

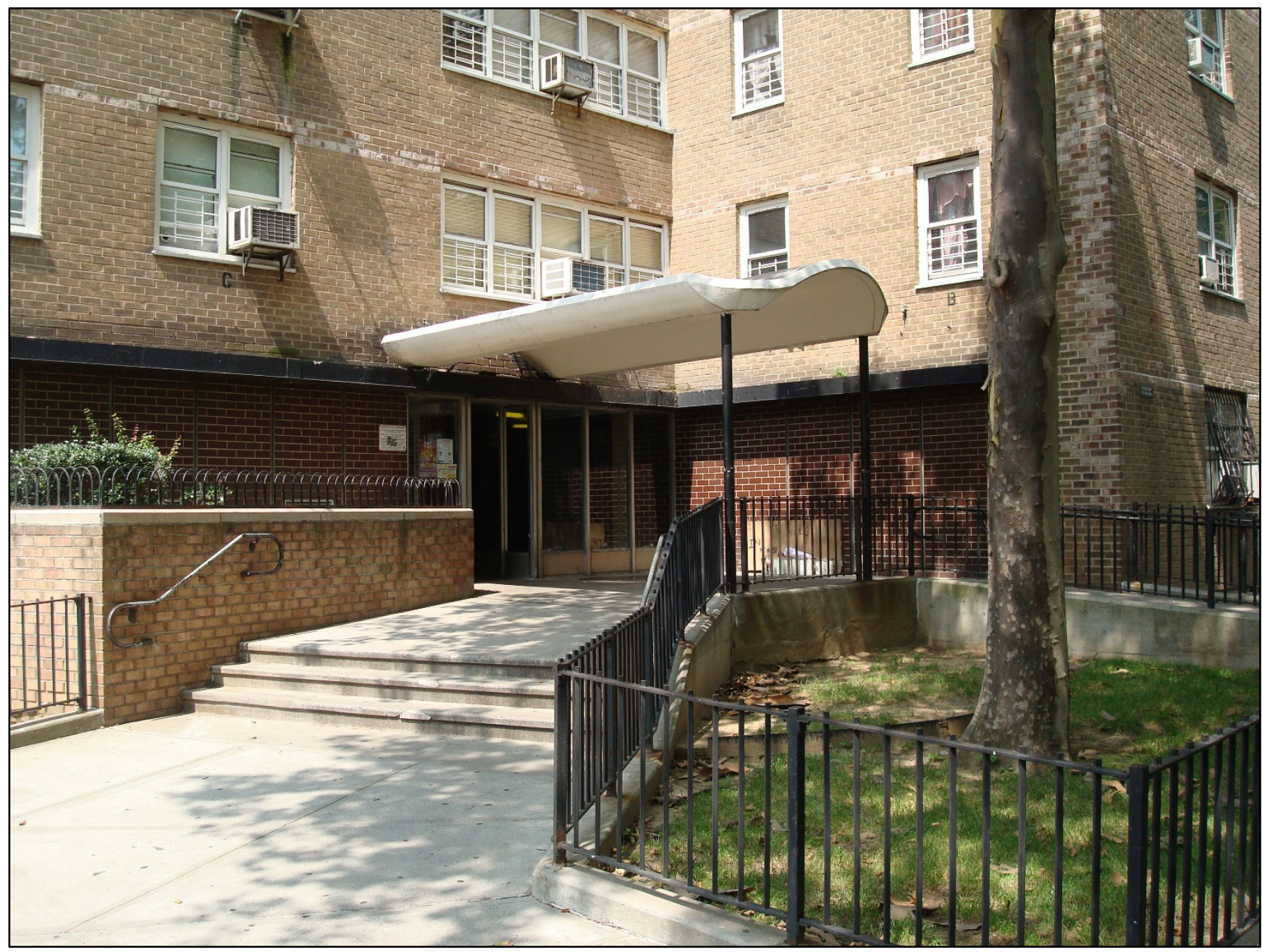

Photo 1. Entrance to main lobby. (NIOSH photo.)

At approximately 2119 hours, the L119 lieutenant radioed to Command that they had control of the door to the fire apartment and were waiting on the hoseline. At approximately 2120 hours, the L119 Roof Man (on the $20^{\text {th }}$ floor) radioed the L119 lieutenant and advised him that the fire appeared to be in the rear bedroom of apartment 19B.

At approximately 2120 hours, the Engine 211 chauffer radioed that the standpipe system was charged. A short time later, the E211 chauffer again radioed that he had water in the system. Division 11 arrived on scene and assumed incident command at 2120 hours. Note: A battalion chief was working the shift as the acting division chief in Division 11. At 2121 hours, the E211 chauffer radioed the E211 lieutenant and advised him "here comes water." 


\section{Career Fire Lieutenant Dies in Cluttered Apartment Fire on 19th Floor of High-rise Residential Building - New York}

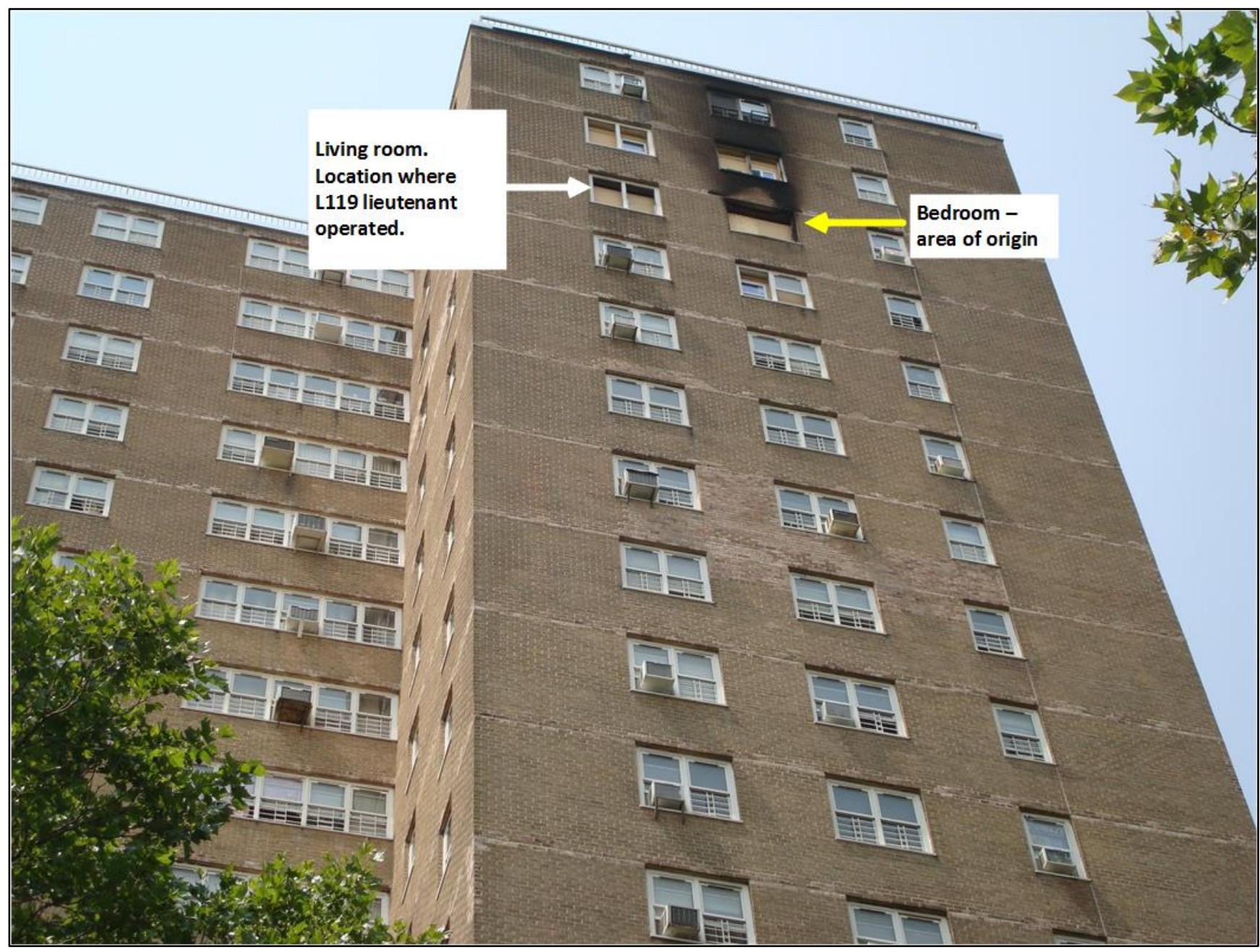

Photo 2. Outside view showing location of fire origin and location of living room where L119 Lieutenant operated. (NIOSH photo.)

The L119 crew was still working on the door when E211's line was charged. The L119 inside team (L119 lieutenant and two fire fighters [Can and Irons]) finished forcing the door and moved into the apartment. The E211 lieutenant and nozzle fire fighter positioned themselves in the hallway outside the apartment and took control of the apartment door. The incident commander (Division 11) radioed the E211 lieutenant and asked for an update. The E211 lieutenant reported that they had their line charged and were waiting for the truck company to find the fire.

At 2121 hours, the L119 outside vent man (elevator control) radioed that there was a problem with fire service on the elevator. Soon after, the Ladder 104 lieutenant radioed Command and advised him that there was no wind on the $20^{\text {th }}$ floor but crews were preparing the window above the fire apartment in case they needed to deploy the fire curtain. BC31 proceeded into the apartment building and heard the 


\section{Career Fire Lieutenant Dies in Cluttered Apartment Fire on 19th Floor of High-rise Residential Building - New York}

radio transmission from the $\mathrm{L} 119 \mathrm{OV}$ that the elevator was malfunctioning so he proceeded to climb the A-stairwell up to the $19^{\text {th }}$ floor.

At 2122 hours, the L119 lieutenant radioed that the apartment was very cluttered. Soon after, another radio transmission also reported cluttered conditions inside the fire apartment. The L119 lieutenant and Can stayed near the right wall and L119 Irons stayed near the left wall as they advanced down the hallway. The L119 crew tried to enter the kitchen but could not due to the cluttered conditions. The L119 crew advanced further down the hallway until they entered the living room (see Diagram 2). They still could not find the fire.

At 2123 hours, Command (D11) radioed the E211 lieutenant and asked if he had water on the fire. The L104 lieutenant radioed Command and advised him that there was going to be an exposure problem on the floor above the fire and requested a hoseline to the $20^{\text {th }}$ floor.

At approximately this time, the E211 lieutenant thought that L119 was taking a long time to find the fire so he entered the apartment to look for the truck company. As soon as he crawled into the apartment he immediately knew what was taking the truck company so long. The apartment was extremely cluttered with objects blocking the interior hallway and stacked high against the walls throughout the apartment making forward movement very difficult. As soon as the E211 lieutenant crawled inside he got stuck on a coat rack. After he untangled himself, he threw the rack into the hallway. He then crawled back inside the apartment and observed the smoke was banking down about halfway to the floor. He reported that he could see about $2-3$ feet with his hand light. As he continued to crawl it became obvious that due to all the clutter it would be easier to duck walk over the top of the clutter. As the E211 lieutenant continued to advance into the apartment he met L119 Irons and asked him where the fire was. L119 Irons replied they couldn't find the fire. At some point, the L119 lieutenant moved further into the living room and went to his right toward the kitchen. This was the last time the L119 lieutenant was seen alive.

The incident commander was able to visibly monitor the fire by moving back and forth from the lobby to the courtyard. The incident commander sent Ladder 108 to the fire floor to be ready to go to work. At this time, L104 reported that they had an auto-exposure issue on the floor above the fire.

At 2124 hours, the L104 roof man radioed the E211 lieutenant and advised him that the fire was in the back, left bedroom. The E211 lieutenant acknowledged the radio transmission.

The E211 lieutenant backed halfway out to the apartment doorway and told the nozzle team to bring the line into the apartment. The L119 Irons also directed the E211 hoseline crew to bring their hoseline down the apartment hallway. The clutter created a real problem for the E211 crew as they advanced straight down the hallway into the apartment. The E211 hoseline crew (two fire fighters [Nozzle and Backup]) advanced their hoseline into the apartment about 5 feet and opened the nozzle. As the E211 crew advanced, they heard someone yell "It's back here." They advanced about 5 feet further. 


\section{Career Fire Lieutenant Dies in Cluttered Apartment Fire on 19th Floor of High-rise Residential Building - New York}

At 2125 hours, the incident commander radioed Engine 210 and asked if they had a high-rise nozzle. The incident commander stated that he wanted the nozzle taken to the $18^{\text {th }}$ floor. He ordered the nozzle be taken to apartment 18B and for the crew to let him know when it was in position. Soon after, the incident commander radioed the L119 lieutenant and asked him for a report on locating the seat of the fire. The incident commander advised the L119 lieutenant that the fire was venting freely out a window on Side Delta. The L119 lieutenant replied that E211 was moving into the apartment and "we got a lot of clutter up here."

At 2127 hours, the L119 outside vent man radioed Command and advised him that the elevator was working again and he was heading back to the lobby. The incident commander radioed L104 and asked for a report above the fire. The L104 lieutenant reported that the search was negative but the windows were going to fail shortly and a fire hose was needed on the $20^{\text {th }}$ floor. At this point, the E211 lieutenant could feel heat to his left but didn't see any fire. The E211 Lieutenant met L119 Can who was using his water can to spray water through the doorway into the bedroom. The E211 Nozzle saw fire rolling overhead as conditions began to deteriorate rapidly. The nozzle was briefly opened to darken down the fire. When the nozzle was opened the hose stream hit L119 Can, knocking his helmet off. Note: At this point, it is believed that the hose stream also hit the L119 lieutenant, although this could not be confirmed. Soon after, the L119 lieutenant radioed Command and advised him that the E211 hoseline was not hitting the fire and conditions in the fire apartment were getting worse. The E211 lieutenant met up with L119 Irons whose low air alarm had just started to activate. The E211 lieutenant showed L119 Irons the way back toward the apartment door.

At 2128 hours, the L119 lieutenant radioed “Mayday, Mayday, Mayday,” which was unheard by most everyone on the scene, (though picked up by distant Handier-Talkie recorders). Immediately after L119 lieutenant's “Mayday" transmission the Engine 211 lieutenant transmitted a "Mayday” that was heard by most everyone at the scene. The incident commander quickly acknowledged the Engine 211 lieutenant's Mayday. Soon after, the E211 lieutenant radioed "I've got fire behind me in the apartment." The incident commander asked the E211 lieutenant if he had the hoseline in operation and the E211 lieutenant replied "Negative.” At this point, the E211 nozzle crew had to back out to let L119 Can and L119 Irons out. One of them bumped into E211 Nozzle. E211 Nozzle and Backup moved the hoseline back to the apartment door and exited the apartment.

At 2129 hours, the L119 lieutenant radioed another Mayday which was not heard by most everyone at the scene. Rescue immediately asked "Who gave a Mayday?" Soon after, the incident commander radioed that the E211 lieutenant was reporting they have fire behind them in the apartment. L119 Can tried to radio the L119 lieutenant with no response.

The E-211 lieutenant crouched down low and dove toward the apartment door where he encountered several fire fighters. At this point, the E211 lieutenant thought he was the last fire fighter to exit the apartment. Once he got to the doorway, he met a chief officer and verbally rescinded the Mayday. However, this was never reported over the radio to the incident commander. At this point, E211 Nozzle's low air alarm began to activate so he moved away from the apartment. E211 Control took 


\section{Career Fire Lieutenant Dies in Cluttered Apartment Fire on 19th Floor of High-rise Residential Building - New York}

the nozzle and he and E211 Backup moved the hoseline back inside the apartment door and resumed operating the attack line in the direction of the bedroom.

At 2130 hours, the L119 lieutenant radioed a third Mayday and stated that he was getting burned bad which went unheard by almost all members at the scene. (Note: This was the last contact with the L119 lieutenant. See Diagram 2 and Photo 2 for the location.)

When BC31 arrived at the fire floor, BC57, who had ridden the elevator, was already there. At this time, BC57 was at the door to the apartment directing companies. E211 Control and E211 Backup continued to operate the attack line in the apartment hallway. They could see fire in front of them and to their left in the bedroom. They tried to bank water off the ceiling and rear wall into the bedroom. E211 Control ran low on air and had to retreat. E211 Backup took over on the nozzle. E211 Control heard a PASS alarm going off in the bedroom. As the E211 Control exited the apartment, he notified everyone he passed of the location of the PASS alarm

Command (Division 11) gave the order to withdraw from the apartment to re-group.

Soon after the order to evacuate was given, Command, located in the courtyard, observed water coming out the window of the fire apartment and the fire appeared to be extinguished. This was approximately $1-2$ minutes after the "Mayday." D-11 radioed R-2 to check if the fire had been extinguished and R-2 replied "Yes." At about this same time, BC31 went to the $20^{\text {th }}$ floor where the fire was extinguished without the need for a hoseline.

After that, Command (Division 11) radioed the L119 lieutenant, but there was no answer. Then command radioed for L119 Irons. L119 Irons reported that he knew where the L119 Can was, but not their officer. BC35 left the command post and proceeded to the fire floor. Rescue 2 and Squad 252 were at the fire room door, and Ladder 110 (FAST Truck) arrived on the fire floor.

Ladder 108 entered the apartment. The hallway was congested with fire fighters trying to advance into the apartment. Debris and accumulated items within the apartment had to be moved out into the public hallway. The Ladder 108 crew members reached the living room and began to knock out the windows to clear the apartment of smoke.

The L119 lieutenant was found at the foot of the bed just past the door swing. The bedroom door had to be removed from its hinges in order to move the L119 lieutenant. It was reported that his facepiece was off. Note: The L119 lieutenant's helmet was found in the living room and the L119 Can's helmet was found in the bedroom. It is believed that both the L119 lieutenant and the L119 Can had their helmets dislodged by the E211 hose stream and the L119 Can moved out of the apartment without a helmet as the heat in the hallway intensified while the L119 lieutenant donned the L119 Can's helmet and attempted to follow but was cut off by the rapidly deteriorating conditions. The L119 Can reported that he never entered the bedroom. 
Career Fire Lieutenant Dies in Cluttered Apartment Fire on 19th Floor of High-rise Residential Building - New York

When BC35 got to the 19th floor in the A-stairwell, he heard Rescue and the Squad calling for a rope. A life rope from the stairwell was given to them. The life rope was hooked up. Soon after, the L119 lieutenant was removed from the fire apartment. When he was pulled out of the apartment, the L119 lieutenant had no mask on his face. BC35 radioed L119 OV who was still operating the elevator and told him to hold it on the 18th floor. After a slight delay in getting the L119 lieutenant into a stokes basket, he was carried down the A-stairwell to the $18^{\text {th }}$ floor and then on the elevator to the ground floor. He was immediately transported to a local hospital where he was pronounced dead.

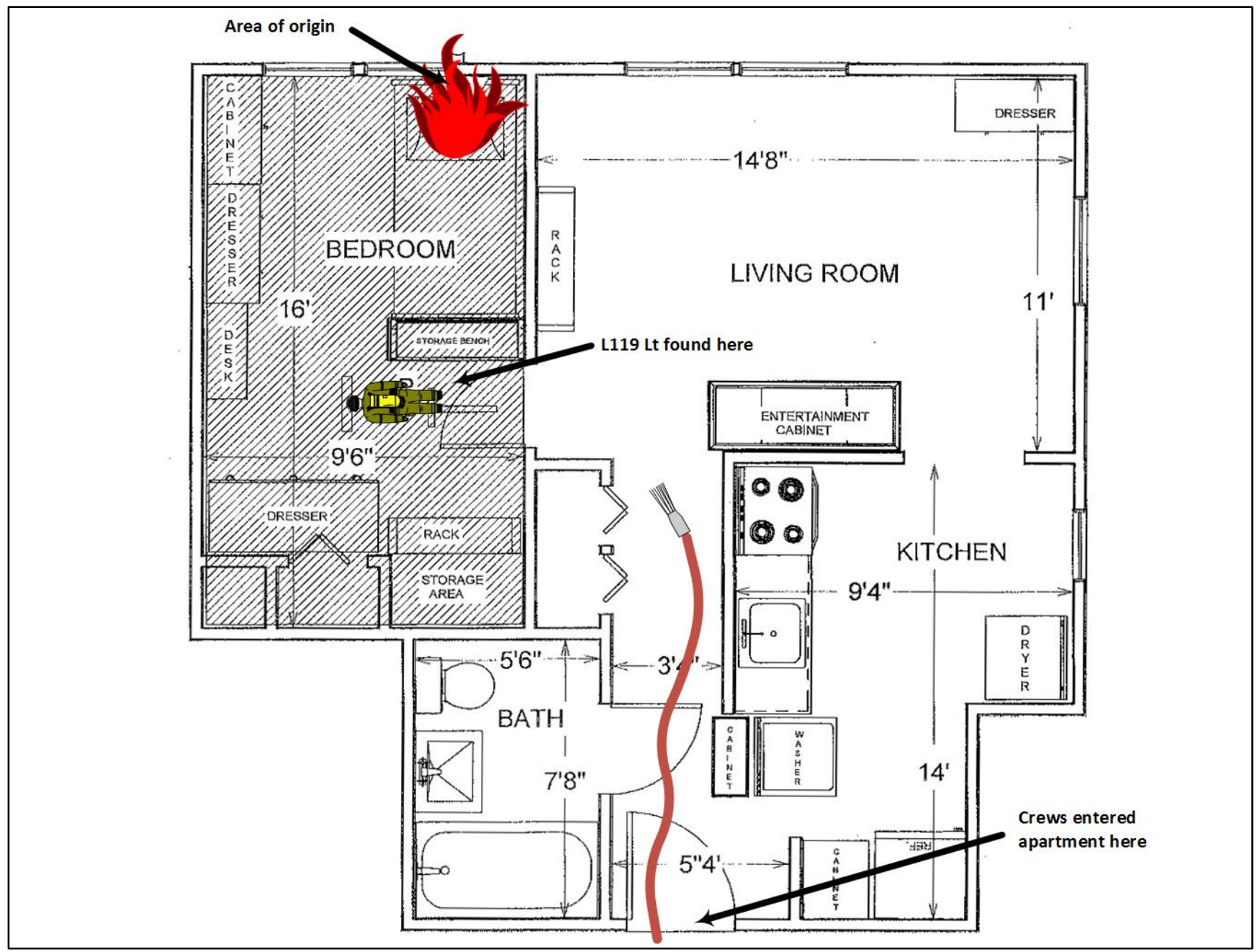

Diagram 2. Diagram shows attack hose placement and location where the L119 lieutenant was found. (Floorplan courtesy of fire department.) 
Career Fire Lieutenant Dies in Cluttered Apartment Fire on 19th Floor of High-rise Residential Building - New York

\section{Fire Behavior}

According to the fire department investigators, the fire was determined to have originated in the bedroom. The cause of the fire was determined to be an overheated extension cord connected to the window-mounted air conditioning unit. The extension cord ran between the wall and the bedframe and extended underneath the hoarded items accumulated in the bedroom.

\section{Indicators of significant fire behavior}

- Fire started by overheated extension cord in bedroom

- Fire started close to bed and accumulated hoarded items

- Fire may have smoldered for some time before fire department arrival

- Initial crews reported smoke but little heat upon entry into the apartment

- Initial crews had trouble locating the fire due to hoarding clutter

- Smoke continued to accumulate inside apartment reducing visibility

- Fire continued to grow in bedroom

- Ladder 104 working on $20^{\text {th }}$ floor advised Command that fire exposure to $20^{\text {th }}$ floor could be a problem after bedroom window (fire apartment on $19^{\text {th }}$ floor) self-vented

- Engine 211 lieutenant reported feeling heat to his left but still couldn’t see fire

- Ladder 119 Can found fire in bedroom and applied water from water can through crack in doorway

- Top of bedroom door burned through allowing fire to extend into living room and ignite fuel rich smoke (see Photo 3 and Photo 4)

- Engine 211 crew reported fire rolling across ceiling in apartment hallway

- Engine 211 opened hoseline but could not hit the fire

- Ladder 119 crew low on air and forced to retreat by heat conditions

- Engine 211 lieutenant radioed Mayday and reported fire was behind him

- Crews forced to retreat and regroup in order to advance hoseline far enough to extinguish fire. 
Career Fire Lieutenant Dies in Cluttered Apartment Fire on 19th Floor of High-rise Residential Building - New York

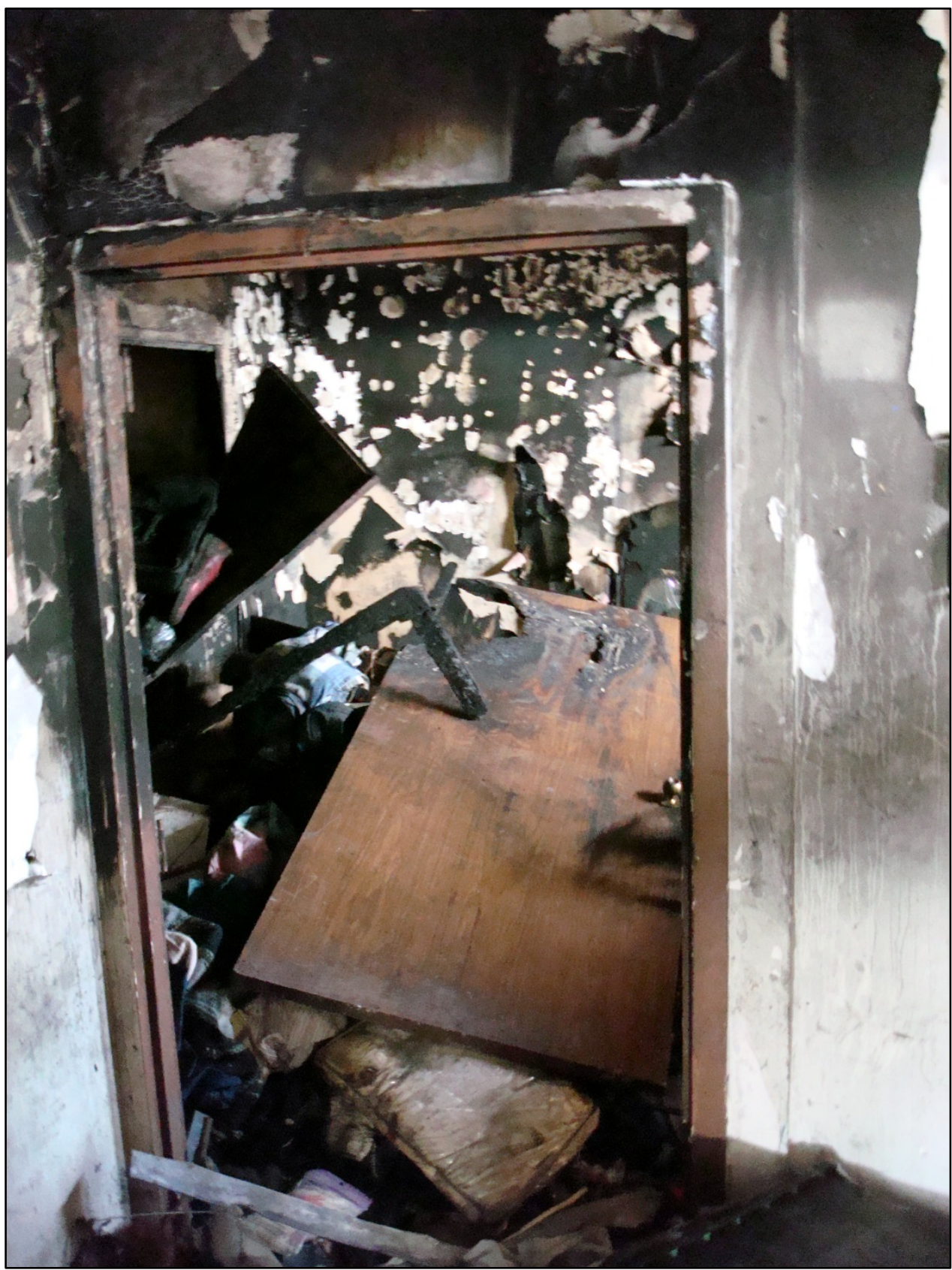

Photo 3. View is from living room looking into bedroom. Note that the door was removed during the recovery operation.

(NIOSH photo.) 
Career Fire Lieutenant Dies in Cluttered Apartment Fire on 19th Floor of High-rise Residential Building - New York

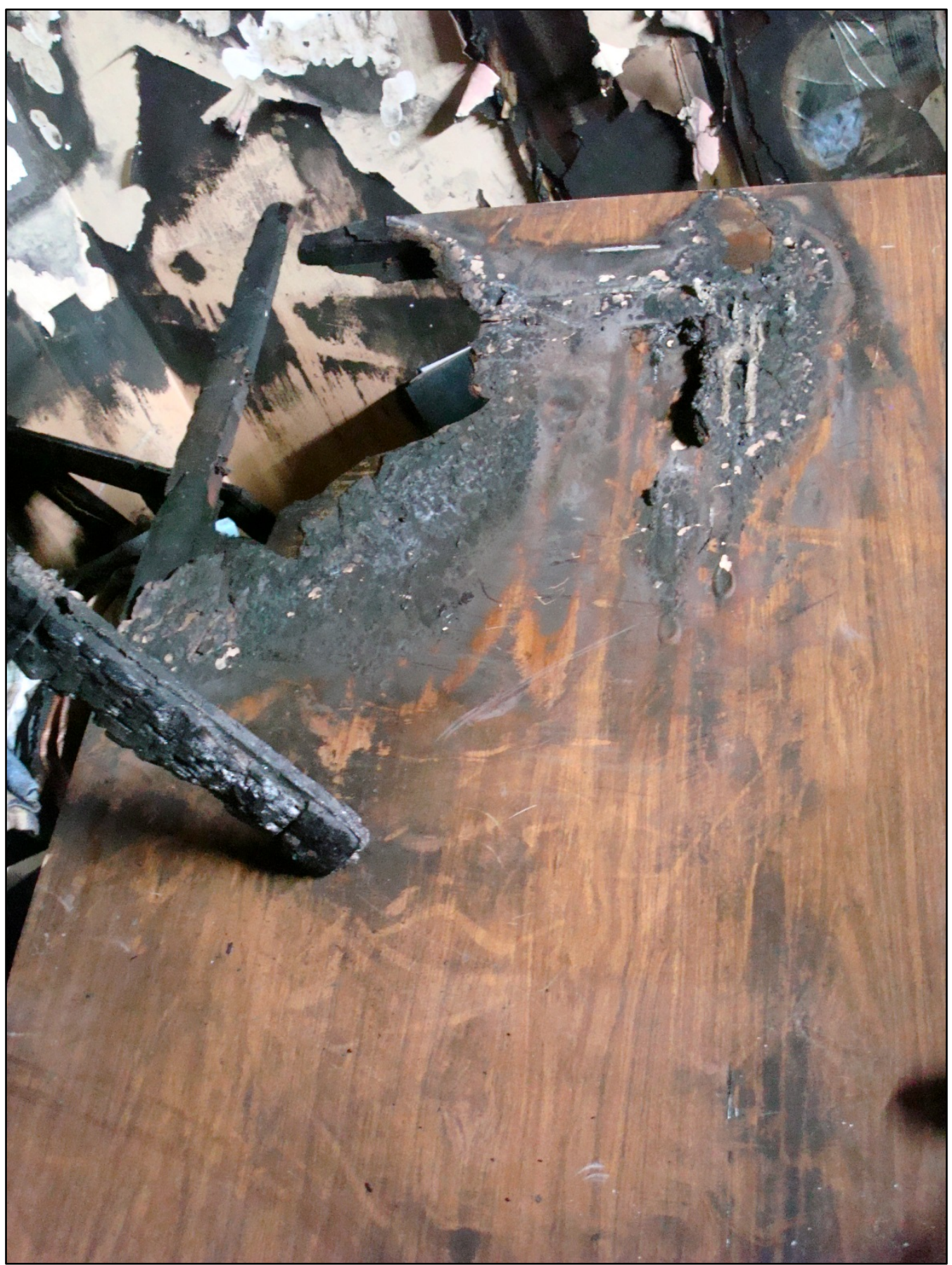

Photo 4. Close-up view of bedroom door. Note the burn-through at top of door. It is believed that the door burned through allowing fire to extend from the bedroom.

$$
\text { (NIOSH photo.) }
$$


Career Fire Lieutenant Dies in Cluttered Apartment Fire on 19th Floor of High-rise Residential Building - New York

\section{Contributing Factors}

Occupational injuries and fatalities are often the result of one or more contributing factors or key events in a larger sequence of events that ultimately result in the injury or fatality. NIOSH investigators identified the following items as key contributing factors in this incident that ultimately led to the fatality:

- Cluttered conditions within apartment blocked ingress and delayed getting water on the fire

- Fire originated in bedroom where extension cord overheated under clutter

- Thick dense smoke limited visibility

- Thick dense smoke became fuel in rapid fire progression

- Lack of water on the fire

- Lack of crew integrity exiting the apartment

- Lack of a sprinkler system in high-rise apartment building

- Radio traffic including Maydays not heard by everyone on fireground

- Defective elevators in high-rise apartment building.

\section{Cause of Death}

According to the death certificate, the medical examiner listed the lieutenant's cause of death as smoke inhalation and thermal burn injuries.

\section{Recommendations}

Recommendation \#1: Fire departments should integrate current fire behavior research findings developed by the National Institute of Standards and Technology (NIST) and Underwriter's Laboratories (UL) into operational procedures by developing standard operating procedures, conducting live fire training, and revising fireground tactics.

Discussion: The National Institute of Standards and Technology (NIST) and Underwriters Laboratories (UL) have conducted a series of live burn experiments designed to replicate conditions in modern homes and residential structures and to validate previous testing done in laboratory settings. The results of these experiments will enable fire fighters to better predict and react to effects of new materials and construction on fire. The fire research experiments were conducted in cooperation with the Fire Department of New York, Chicago Fire Department, Spartanburg South Carolina Fire and Rescue, and other agencies. The live burn tests are aimed at validating emerging theories about how fires are different today, largely due to new building construction and the composition of home furnishings and products. In the past, these products were mainly composed of natural materials, such as wood and cotton, but now contain large quantities of petroleum-based products and synthetic materials that burn faster and hotter and also generate large volumes of fuel-rich smoke. Where a fire in a room once took approximately 20 minutes to flashover-igniting all the contents - this can happen with today's products in as little as 4 to 5 minutes [NIST, UL 2013].

In addition, modern living spaces tend to be more open, less compartmentalized and are better insulated than homes built years ago. As a result, interior residential fires can generate oxygendepleted, fuel-rich environment within minutes. This fire condition of hot, fuel-rich smoke is highly 


\section{Career Fire Lieutenant Dies in Cluttered Apartment Fire on 19th Floor of High-rise Residential Building - New York}

reactive to the introduction of oxygen. Introducing oxygen to this environment by opening a door or venting a window may result in a rapid transition to an extreme fire event or flashover. These same conditions can occur in commercial structures as seen in the fire at the Charleston, South Carolina, Sofa Super Store [NIOSH 2009].

The NIST and UL experiments evaluated individual and combinations of methods for strategically ventilating and isolating fires to prevent flashover-or at least delay it. In contrast, kicking a door open or breaking a window without knowledge of conditions inside could create a portal for air that can literally fan the flames by introducing oxygen into an oxygen-limited fire environment.

Traditionally, fire suppression operations were conducted from the interior of the structure as a means to reduce water damage and limit fire damage to structures. These operations must be coordinated with the ventilation operations. Previous research and examinations of line-of-duty deaths have shown that ventilation events occurring with fire fighters in the structure prior to suppression have led to tragic results [NIOSH 2009, 2012, 2013]. One means of eliminating the possibilities of this occurrence would be a transitional attack, in which water is directed into the structure from the exterior to cool the fire gases and reduce the heat release rate of the fire, prior to the fire fighters entering the building. The major concern with this type of operation is the potential harm that might occur to people trapped in the structure or the amount of water damage to the structure. Therefore, measurements are needed to document the changes of the thermal environment within the structure and the impact on the survivability of people who might be trapped in the structure [NIST, UL 2013].

Based upon the NIST and UL research, certain considerations should be given before implementing each of the following fireground operations:

- Size-Up

Size-up must occur at every fire. Consideration must be given to the resources available and situational conditions, such as weather, fire location, size of the fire and building, and the construction features. Ensure a 360-degree size-up is conducted whenever possible. A tactical plan for each fire must be developed, communicated, and implemented [NIST, UL 2013].

- Ventilation

Fire departments should manage and control the openings to the structure to limit fire growth and spread and to control the flow path of inlet air and fire gases during tactical operations. All ventilation must be coordinated with suppression activities. Uncontrolled ventilation allows additional oxygen into the structure, which may result in a rapid increase in the fire development and increased risk to fire fighters due to increased heat release rates within the flow path [NIST, UL 2013].

- $\quad$ Fire fighting Operations

Given the fuel-rich environment that the fire service operates in today, water should be applied to the fire as soon as possible. In many cases, water application through an exterior opening 


\section{Career Fire Lieutenant Dies in Cluttered Apartment Fire on 19th Floor of High-rise Residential Building - New York}

into a fire compartment may be the best first action, prior to committing firefighting resources to the interior.

Fire departments should cool the interior spaces of a fire building with water from the safest location possible, prior to committing personnel into spaces with, or adjacent to, fully developed or smoldering (ventilation limited) fire conditions [NIST, UL 2013].

\section{- Rapid Intervention}

Fire department rapid intervention procedures should be updated to provide water on the fire as soon as possible and ventilation openings controlled during fire fighter Mayday incidents [NIST, UL 2013].

This information is presented to educate the fire service and to ensure that fire departments consider a change in fireground tactics based upon the current research presented by NIST and UL. Much of this research has been directed toward developing a better understanding of the characteristics of the modern fire. This modern research provides members of the fire service with the information and knowledge needed to modify essential fire-fighting tactics. While fire-fighting will never be without risk, this research represents a vital contribution to overall efforts to reduce risks and to save lives.

This fire department has been actively involved in the NIST and UL modern fire behavior research and has a number of detailed standard operating procedures in place based upon this research.

In this incident, not all fire fighters working to locate the seat of the fire in the 500-square foot apartment may have recognized the hazard of the thick dense smoke contributing to the fire load. Conditions inside the apartment suddenly and rapidly deteriorated, forcing the Ladder 119 and Engine 211 crews to retreat to the hallway. At some point, the Ladder 119 lieutenant became separated from the rest of his crew and did not escape.

\section{Recommendation \#2: Fire departments should have a written risk management plan, use risk management principles at all structure fires and especially at incidents involving high risk hazards.}

Discussion: While it is recognized that fire fighting is an inherently hazardous occupation, established fire service risk management principles are based on the philosophy that greater risks will be assumed when there are lives to be saved and the level of acceptable risk to fire fighters is much lower when only property is at stake. Interior (inside a structure) offensive fire-fighting operations can increase the risk of traumatic injury and death to fire fighters from structural collapse, burns, and asphyxiation. Established risk management principles suggest that more caution should be exercised in abandoned, vacant, and unoccupied structures and in situations where there is no clear evidence indicating that people are trapped inside a structure and can be saved [NIOSH 2010].

The incident commander (IC), with input from the assigned Incident Safety Officer and/or Division/Group Supervisors, is responsible for evaluating conditions at a structure fire and determining 


\section{Career Fire Lieutenant Dies in Cluttered Apartment Fire on 19th Floor of High-rise Residential Building - New York}

safe tactics for fighting the fire. To accomplish this, the IC should use a standardized strategic decision-making model. First, the IC should size up the critical fireground factors [NIOSH 2010].

The incident commander must make a determination that offensive (interior) operations may be conducted without exceeding a reasonable degree of risk to fire fighters before ordering an offensive attack and must be prepared to discontinue the offensive attack if the risk evaluation changes during the fire fighting operation. A full range of factors must be considered in making the risk evaluation, including (but not limited to):

- $\quad$ Presence of occupants in the building

- $\quad$ A realistic evaluation of occupant survivability and rescue potential

- $\quad$ Size, construction, and use of the building

- $\quad$ Age and condition of the building

- $\quad$ Nature and location of building contents

- $\quad$ Location and extent of the fire within the building

- $\quad$ Adjacent exposures (structures)

- $\quad$ Fire involvement or compromise of the building's structural components

- $\quad$ Considerations of fire loading and fire behavior

- A realistic evaluation of the ability to execute a successful offensive fire attack with the resources that are available [NIOSH 2010].

These fireground factors must be weighed against the risk management plan. There is absolute recognition of the fact that fire fighters are routinely exposed to certain known and predictable risks while conducting operations that are directed toward saving property. The Incident Commander is responsible for recognizing and evaluating those risks and determining whether the level of risk is acceptable or unacceptable. However, risks taken to save property should always be lesser than those to save lives [NIOSH 2010]. Risks to fire fighters versus gains in saving lives and property must always be considered when deciding whether to use an offensive or defensive attack. The Incident Commander should routinely evaluate and reevaluate conditions and radio progress reports in reaching objectives to dispatch and on-scene fire fighters. This process allows the Incident Commander to determine whether to continue or revise the strategy and attack plans. Failure to revise an inappropriate or outdated attack strategy is likely to result in an elevated risk of death or injury to fire fighters [NFPA 2013c, NIOSH 2010].

Retired New York City Deputy Fire Chief Vincent Dunn states the following: "When no other person's life is in danger, the life of the firefighter has a higher priority than fire containment” [Dunn 1999]. Chief Dunn also states "The protection of life is the highest goal of the fire service... When a life is clearly threatened, there is no risk too great. At most fires, however, lives are not clearly endangered. At most fires, then, the priority of firefighting is the protection of the fire fighters' lives.”

Standard operating procedures should be specific to reduce risks to fire fighters. Crew integrity should be maintained at avoid members operating by themselves. Consideration should include changing the tactical operations so that a crew remains intact or members are paired at all times in all operations. Members operating in hazardous areas at emergency incidents should operate in crews of two or more. 


\section{Career Fire Lieutenant Dies in Cluttered Apartment Fire on 19th Floor of High-rise Residential Building - New York}

[NFPA 2013c]. NFPA 1250 Recommended Practice in Fire and Emergency Service Organization Risk Management establishes the minimum criteria to develop, implement or evaluate a fire and emergency service organization (FESO) risk management program for effective risk identification, control and financing. This NFPA recommended practice is intended to provide those with the responsibility for risk management with a process to control or minimize the impact of detrimental events on the FESO and governing authority [NFPA 2015].

In general terms, the risk management plan must consider the following: (1) risk nothing for what is already lost — choose defensive operations; (2) extend limited risk in a calculated way to protect savable property - consider offensive operations; (3) and extend very calculated risk to protect savable lives-consider offensive operations [IAFC 2012, NIOSH 2010]. NFPA 1500 Standard on Fire Department Occupational Safety and Health Program, Chapter 8.3 addresses the use of risk management principles at emergency operations. Chapter 8.3.4 states that risk management principles shall be routinely employed by supervisory personnel at all levels of the incident management system to define the limits of acceptable and unacceptable positions and functions for all members at the incident scene. Chapter 8.3.5 states that at significant incidents and special operations incidents, the Incident Commander shall assign an incident safety officer who has the expertise to evaluate hazards and provide direction with respect to the overall safety of personnel. The annex to Chapter 8.3.5 contains additional information. Modern incident demands on the fireground are unlike those of the recent past, requiring incident commanders and commanding officers to have increased technical knowledge of building construction with a heightened sensitivity to fire behavior, a focus on operational structural stability and considerations related to occupancy risk versus the occupancy type. Strategies and tactics must be based on occupancy risk, not occupancy type, and must have the combined adequacy of sufficient staffing, fire flow and tactical patience orchestrated in a manner that identifies with the fire profiling, predictability of the occupancy profile and accounts for presumptive fire behavior. NFPA 1500, Section 8.3.2 states that in situations where the risk to fire department members are excessive, activities shall be limited to defensive operations [NFPA 2013c].

This incident occurred in a 21-story high-rise residential building that represented a high-risk structure. The fire apartment was extremely cluttered which presented high risk hazards due to the limited mobility presented to crews entering the apartment. The fire department had detailed high-rise procedures in place at the time of this incident. The incident commander was in the process of pulling everyone out of the fire area and was setting up for an outside attack using a high rise nozzle when the fatality occurred.

Recommendation \#3: Fire departments should ensure that crew integrity is properly maintained by voice or radio contact when operating in an immediately dangerous to life and health (IDLH) atmosphere.

Discussion: When a crew enters a structure, the members should remain in contact by visual (eye-toeye), verbal (by radio or person-to-person), or direct (by touch) contact. NFPA 1500 Standard on Fire Department Occupational Safety and Health Program, states in Paragraph 8.5.5, "Crew members operating in a hazardous area shall be in communication with each other through visual, audible, or 


\section{Career Fire Lieutenant Dies in Cluttered Apartment Fire on 19th Floor of High-rise Residential Building - New York}

physical means or safety guide rope, in order to coordinate their activities." Additionally, NFPA 1500 Paragraph 8.5.6 states, "Crew members shall be in proximity to each other to provide assistance in case of an emergency" [NFPA 2013c].

The International Association of Fire Chiefs, Safety, Health, and Survival Section has redefined the Rules of Engagement for Structural Fire Fighting. One of the objectives is to ensure that fire fighters always enter a burning building as a team of two or more members and no fire fighter is allowed to be alone at any time while entering, operating in, or exiting a building. A critical element for fire fighter survival is crew integrity. Crew integrity means fire fighters stay together as a team of two or more. They should enter a structure together and remain together at all times while in the interior, and all members come out together. Crew integrity starts with the company officer ensuring that all members of the company understand their riding assignment, have the proper personal protective equipment, and have the proper tools and equipment. Upon arrival at the incident, the company is given a task to perform by the incident commander. The company officer communicates to the members of the company what their assignment is and how they will accomplish their assignment. As the members of a company enter a hazardous environment together, they should leave together to ensure that crew integrity is maintained. If one member has to leave, the whole company leaves together [IAFC 2012].

It is the responsibility of every fire fighter to stay in communications with crew members at all times. All fire fighters should maintain the unity of command by operating under the direction of the incident commander, division/group supervisor, or their company officer at all times. The ultimate responsibility for crew integrity and ensuring no members get separated or lost rests with the company officer. They should maintain constant contact with their assigned members by visual observation, voice, or touch while operating in a hazard zone. They should stay together as a company or crew. If any of these elements are not adhered to, crew integrity is lost and fire fighters are placed at greater risk. If a fire fighter becomes separated and cannot re-connect with his/her crew immediately, the fire fighter should attempt to communicate via portable radio with the company officer. If reconnection is not accomplished after three radio attempts or reconnection does not take place within 1 minute, a Mayday should be declared. If conditions are rapidly deteriorating the Mayday should be declared immediately. As part of a Mayday declaration, the fire fighter should next activate the radio's emergency alert button (where provided) followed by manually turning on the PASS alarm. Similarly, if the company officer or the fire fighter's partner recognizes they have a separated member, they should immediately attempt to locate the member by using their radio or by voice. If contact is not established after three attempts or within one minute a Mayday should be declared immediately [IAFC 2012]

The fire department involved in this incident had standard operating procedures in place at the time of this incident that stressed maintaining crew integrity. In this incident, the conditions within the apartment rapidly deteriorated as the Ladder 119 Irons ran low on air and the Ladder 119 Can lost his helmet. The Ladder 119 lieutenant became separated from his crew after the conditions inside the apartment rapidly deteriorated. The Ladder 119 lieutenant was not able to escape. 


\section{Career Fire Lieutenant Dies in Cluttered Apartment Fire on 19th Floor of High-rise Residential Building - New York}

Recommendation \#4: Fire departments should consider changes to firefighting search operations to include the use of search lines or hose lines as a means to exit an occupancy.

Discussion: Fire departments should consider changing fire ground tactics based upon current best practices. These changes in tactical operations should be considered not only for high rise operations but all structure fire fighting to include search techniques to determine the location of a fire or search for occupants. A search line or hose line should be used so that firefighters can find their way out of the occupancy or fire compartment/room if needed.

A search line or hose line should be viewed as a lifeline to the outside. Fire fighters advancing a hose line should remain in contact with the hose as it is advanced into an occupancy and be able to read hose couplings by touch with gloves on under zero visibility conditions to determine which direction leads to a safe exit at the point of entry. Search lines can be used to keep fire fighters connected to a point of egress while searching an area. Although a hose line is preferred, search lines may be necessary when the time available to make a rescue is critical. A search line must be anchored to a fixed point that leads directly to a safe egress. Some departments attach a search line to the fire attack nozzle to conduct a fan out approach to search an area. The general rule is: the further the hose line must be extended, the more personnel required. Additional fire fighters are needed to guide the hose line around obstacles and to keep the hose line free from entanglements. The additional fire fighters on the line also act as safety personnel. In general, a hose line should be used when entering an occupancy [IAFF 2012, NIMS 2008, Phoenix FD, Los Angeles FD 2006, 2016].

The fire department involved in this incident has detailed standard operating procedures covering the use of rescue ropes (search lines) and when they should be deployed. In this incident, L-119 entered into the 500 square-foot residential occupancy that had a hoarding condition in front of a hose line. At the time L-119 made entry, E-211 was also at the door with a hose line and waited for L-119's attempt to locate the fire. The hose line was used by both the L119 Can and Irons to find their way back to the apartment door.

Recommendation \#5: Fire departments should ensure that all fire fighters are trained on the unique hazards presented by hoarding and standard operating procedures are developed and enforced to provide guidance for fire fighters confronted with hoarding conditions.

Discussion: Hoarding conditions can present unique and unexpected hazards during interior fire fighting operations. Moving through the cluttered interior of a hoarder house can pose several challenges. Fire fighters may be forced to climb over or on top of the hoarded materials. These materials may present multiple obstacles that can snag the fire fighters' clothing, equipment and selfcontained breathing apparatus. Entanglement is a real possibility. Climbing over hoarded materials can cause the fire fighter, trained to stay low in the coolest thermal layer possible during interior fire fighting operations, to inadvertently move higher into hotter thermal layers [IAFC 2015]. Hoarding conditions can turn the two-dimensional floor into a three-dimensional surface [IAFC 2015]. Hoarding conditions can slow down the forward advancement of the fire attack hose. By definition, a hoarding condition could be considered an urban search and rescue (USAR) condition because it has 


\section{Career Fire Lieutenant Dies in Cluttered Apartment Fire on 19th Floor of High-rise Residential Building - New York}

limited or restricted means for rescue or exit and contains a recognized serious safety or health hazard that could require a rope rescue into the hazardous area.

Fire departments should develop standard operating procedures that address hoarding conditions and require that all fire fighters are trained on these procedures. The procedures should present options for fire fighters to operate safely during firefighting in hoarded conditions. Such procedures may suggest maintaining a defensive position at the hallway door with a charged hose line, and a second fire attack line could be taken into the adjoining occupancy. Breaching of a common wall to reach the fire could provide a better and safer tactical position to apply water on the fire. If a common wall is not available, then another option could be opening a hole in the floor above the fire room and putting a hose stream into the hole to act like a sprinkler head to knock down the fire. In a high rise occupancy, a cement-cutting blade may be necessary to cut through the concrete in the floor construction. A thermal imager should be used to locate the heat in an adjoining common wall or in determining the safest location above a fire.

In this incident, crews reported that the hoarding conditions inside the 500 square-foot apartment hindered their movement within the apartment and delayed their finding the seat of the fire. Crew members reported having to move objects out of the way as soon as they entered the apartment door. Some fire fighters reported having to duck walk over top of the hoarded materials. At least one fire fighter reported getting tangled up while advancing down the hallway. It is possible that the hoarding conditions restricted the ability of the L-119 lieutenant to escape. Crews were not able to get water onto the seat of the fire until after the fatality had occurred.

\section{Recommendation \#6: Fire departments should ensure that fire fighters are properly trained in air management.}

Discussion: Chief Bobby Halton, retired fire chief and currently editor-in-chief of Fire Engineering notes, "If you run out of air in a working fire today, you are in mortal danger. There is no good air at the floor anymore, no effective filtering methods, no matter what others may say to the contrary." The only protection for fire fighters in the toxic smoke environments in today's fires is the air that they carry on their backs. Like SCUBA divers, fire fighters must manage their air effectively to leave enough reserve air to escape in case of unforeseen occurrences while inside a structure fire. Fire fighters must manage their air so that they leave the immediately-dangerous-to-life-or-health (IDLH) atmosphere before the low-air alarm activates. This leaves an emergency air reserve and removes the noise of the low-air alarm from the fireground [Gagliano et al, 2008]. Air management is a program that the fire service can use to ensure that fire fighters have enough breathing air to complete their primary mission and to escape an unforeseen emergency. Fire departments and fire fighters need to recognize that the smoke in modern construction is an IDLH atmosphere and manage their air along with their work periods so the fire fighters exit the IDLH atmosphere with their reserve air intact. NFPA 1404 Standard for Fire Service Respiratory Protection Training states that fire fighters should exit from an IDLH atmosphere before the consumption of reserve air supply begins; a low-air alarm is notification that the individual is consuming the reserve air supply and activation of the reserve air alarm requires immediate action of the individual and the fire-fighting team [NFPA 2013b] 


\section{Career Fire Lieutenant Dies in Cluttered Apartment Fire on 19th Floor of High-rise Residential Building - New York}

The vast majority of the structure fires responded to are single or multi-family residential occupancies. For some fire departments, a typical strategy is an aggressive offensive fire fight to achieve the tactical priorities. Generally, fire crews are able to search these structures quickly, put out the fire, and exit the hazard zone without having to give much thought to air management. Multiple points of egress are usually close by should a rapid retreat to the exterior become necessary. High-rise apartment buildings present additional challenges that fire fighters must consider.

It's critical to insure fire fighters exit the hazard zone with an emergency reserve of air. According to NFPA 1404, all members using an SCBA in the hazard zone of an incident shall monitor the amount of air in their SCBA cylinder as well as their rate of air consumption in order to exit the hazard zone prior to the low air alarm activation of the SCBA [NFPA 2013b]. Just as ocean divers are trained to surface with an emergency reserve of air, fire fighters shall exit the hazard zone of an incident with an emergency reserve of air. It is critical that fire fighters understand that the initial $67 \%$ of the air supply is the "working and exiting air" [NFPA 2013e]. This includes air used for gaining access, working toward the tactical objectives, and exiting the hazard zone.

Company officers should frequently assess their crew's air consumption rates and decide the crew's exit time based on the individual with the greatest assumed air consumption rate. It is the individual fire fighter's responsibility to continually assess and report his/her air consumption to his/her company officer.

In this incident a number of fire fighters ran low on air and had to exit the apartment. The L119 lieutenant's SCBA cylinder was empty when it was examined by NIOSH NPPTL.

\section{Recommendation \#7: Fire Departments should develop, implement and enforce written SOPs to ensure that SCBA cylinders are fully charged and ready for use by ensuring that SCBA are inspected at the beginning of every shift.}

Discussion: This recommendation is given as a recognized best safety practice for all fire departments. An important aspect of air management is to ensure that the SCBA air cylinder is always full prior to use. Checking the SCBA air cylinder pressure should be part of the daily equipment check process at the beginning of every shift. Fire fighters should also check the air pressure when SCBA are donned for use at emergency operations. The OSHA Respirator Standard, 29 CFR 1910.134(h)(3)(iii) states "Air and oxygen cylinders shall be maintained in a fully charged state and shall be recharged when the pressure falls to $90 \%$ of the manufacturer's recommended pressure level."[OSHA 1998]. NFPA 1852 and good SCBA practice dictate that SCBA air cylinders be refilled whenever the cylinder pressure falls to $90 \%$ of the manufacturer's recommended pressure level [NFPA 2013d, Peterson and Merinar, 1997]. A 30-minute cylinder typically holds 1,200 liters of air when fully charged. A cylinder charged to 1,500 psi would hold approximately 812 liters of air. A fire fighter working at a moderate work rate (40 liter per minute air consumption rate) would exhaust a cylinder holding 1500 psi in approximately 20 minutes (812 liters divided by 40 liters per minute). Fire fighters working at a higher work rate or 


\section{Career Fire Lieutenant Dies in Cluttered Apartment Fire on 19th Floor of High-rise Residential Building - New York}

breathing under duress (such as in an emergency situation) would exhaust a cylinder much quicker. During extreme exertion, the actual service time can be reduced by 50 percent or more [NFPA $2013 \mathrm{~d}$ ].

The daily equipment check process at the beginning of every shift should include a visual check of the SCBA cylinder pressure. The cylinder pressure should be recorded on the daily equipment check sheet. It is also important to note that all SCBA should be properly maintained according to NFPA 1852 Standard on Selection, Care, and Maintenance of Open-Circuit Self-Contained Breathing Apparatus (SCBA) [NFPA 2013d].

The fire department involved in this incident has standard operating procedures covering daily equipment checks at the beginning of each shift. In this incident, the L119 lieutenant supervised the inspection of all SCBA on Ladder 119 and entered the results in the company's daily inspection records (referred to as the Company Journal). This entry indicates that the masks were inspected and that any defective SCBAs or low cylinders were replaced. It also indicates that at the time of the entry all SCBA passed inspection. This is done at the change of tours twice daily and the entry follows the Roll Call entry for each tour.

\section{Recommendation \#8: Fire departments should ensure fire fighters are trained in self-contained breathing apparatus (SCBA) emergencies.}

Discussion: Repetitive skills training with SCBA is vital for fire fighters working inside an IDLH atmosphere. SCBA skills training is an ongoing process that should be performed regularly to ensure that fire fighters "know their SCBA." The benefits of repetitive skill training with SCBA are an increased comfort and competency level, decreased anxiety, lower air consumption, increased awareness of the user's air level, noticing and using the heads-up display (HUD), and an automatic muscle memory response to the vital function controls, such as the don/doff buttons, main air valve, emergency bypass operating valve, rapid intervention crew/universal air connection (RIC/UAC) and the buddy-breather connection. Repetitive skills training can also provide the user with an increased ability to operate these functions and controls in a high-anxiety moment or an emergency. Many times it is necessary to perform these skills with gloved hands, limited vision, and reduced ability to hear commands from others. Performed in conditions that are non-IDLH, repetitive skills training helps build the fire fighters' muscle memory skills so their hands will be able to activate the controls with gloves on and the operation will be a conditioned or second-nature response. Fire fighters have died in IDLH conditions because they did not react properly to a malfunctioning SCBA or out-of-air emergency [NIOSH 2011].

Fire fighters should never remove their facepiece in an IDLH atmosphere. Self-contained breathing apparatus may experience partial or total malfunctions. or example, if a regulator malfunctions a fire fighter can often open the emergency bypass valve to purge the exhalation valve or get air. If the pressure-reducer malfunctions, airflow can be controlled by partially closing the cylinder valve to get some flow of air. The key to most situations is to not panic and concentrate on skills training. Most procedures recommend calling for help and/or activating your PASS device, and attempting to exit the structure. An emergency training protocol should be established for each type of SCBA in an 


\section{Career Fire Lieutenant Dies in Cluttered Apartment Fire on 19th Floor of High-rise Residential Building - New York}

emergency situation and utilize programs compliant with NFPA 1404 Standard for Fire Service Respiratory Protection Training [NFPA 2013b]. It is also important to note that all SCBA should be properly maintained according to NFPA 1852 Standard on Selection, Care, and Maintenance of OpenCircuit Self-Contained Breathing Apparatus (SCBA) [NFPA 2013d].

The fire department involved in this incident has standard operating procedures that address selfcontained breathing apparatus emergencies. In this incident, the Ladder 119 lieutenant was found with his facepiece, and helmet off. His SCBA was out of air and the facepiece lens and the eye shields on the helmet found in the fire area had thermal damage which may have contributed to the depletion of his SCBA air and caused him to remove his facepiece. He was able to radio a final Mayday at approximately 2130 hours.

Recommendation \#9: Fire departments should ensure that the incident commander establishes a stationary command post for visibility and effective incident management, which includes the use of a tactical worksheet, efficient fireground communications, and a personnel accountability system.

Discussion: Although there is no clear evidence that this recommendation would have prevented this fatality, the recommendation is presented as good fireground safety practice. NFPA 1561 Standard on Emergency Services Incident Management System and Command Safety §5.3.1 states, "The incident commander shall have overall authority for management of the incident.” The incident commander must establish and maintain a command post outside of the structure in order to assign companies, delegate functions, and continually evaluate the risk versus gain of continued fire-fighting efforts [NFPA 2014].

Command safety principles provide the incident commander a foundation for effective and efficient management of Type IV and Type V incidents and ensures the highest level of safety for fire department members at emergency incident scenes. This system defines requirements that the incident commander must meet during an incident, including the establishment of a stationary command post and utilization of a tactical worksheet, effective fireground communications, and a personnel accountability system.

When a chief officer (e.g., battalion chief, district chief) arrives on scene, the first steps are to assume command, announce the name of the incident (e.g., Main Street Command), and establish a stationary, exterior, and remote command position. Once command is established and an initial size-up has been done, the incident commander should continue command and control functions inside or at the rear of the vehicle, which should have a command board [Ciarrocca and Harms 2011].

In establishing a command post, the incident commander shall ensure the following (NFPA 1561, Chapter 8-Command Safety):

- The command post is located in or tied to a vehicle to establish presence and visibility.

- The command post includes radio capability to monitor and communicate with assigned dispatch, tactical command, and other designated emergency traffic channels for that incident.

- The location of the command post is communicated to the communications center. 


\section{Career Fire Lieutenant Dies in Cluttered Apartment Fire on 19th Floor of High-rise Residential Building - New York}

- The incident commander, or designee, is always present at the command post.

- The command post should be located in the incident cold zone [NFPA 2014].

In order to effectively command an incident, the incident commander should be in the most advantageous position possible. The best position is a fixed, visible, and accessible location at the command post. This can be accomplished by utilizing the incident commander's staff vehicle, a designated command vehicle, or fire apparatus. An acceptable alternative is utilizing the rear area of a sport utility vehicle or van-style vehicle. This method will provide the incident commander with an area that is quiet and free of distractions from which to command an incident. It is also vital for the incident commander to be able to hear all radio transmissions, especially from those operating on scene. The best way to accomplish this is through the use of a radio communication headset. This will enable the incident commander to be in the best position possible to hear critical radio transmissions. The incident command post also should be visible and recognizable. This can be accomplished by displaying a colored light, flag, banner, or other symbol to mark the location. Where special command post vehicles are used, such vehicles are usually marked with distinctive identification to make the command post recognizable [NFPA 2014].

The tactical worksheet is a critical piece of equipment because it helps the incident commander organize tasks by providing reminders, prompts, and a convenient workspace for tracking companies and apparatus. It allows them to slow down during what could be a large, multi-alarm incident, although the worksheet can be used for fires big and small, as well as EMS incidents, to help develop proficiency and to record vital information that may help them make future operational decisions. By documenting the assignments of division/group officers and division/group resources, the incident commander creates a visual reference of the overall fireground organization and deployment [Los Angeles Fire Department 2011].

The tactical worksheet is also an excellent tool when the passing of command occurs. On the fireground, the officer taking over command can quickly check the worksheet and obtain a strong understanding of the initial deployment of resources, the need for additional apparatus and equipment, and the status of units in the staging area. The advantages of using a tactical worksheet are that it:

- Includes a location to quickly note individual assignments

- Provides prompts for the incident commander, such as time, air management, and strategy

- Provides tactical benchmarks, such as primary search complete, fire under control, and loss stopped

- Facilitates consistent, organized information

- Documents assignments and responsibility

- Expedites passing of command or support for the incident commander

- $\quad$ Provides resource status. [NFPA 2014]

Fire departments should have a communications standard operating procedure (SOP) coupled with an effective training program. These procedures include the use of clear text (specifically, no 10 codes, or other terms that may be unfamiliar to other responders), a separate radio channel for dispatch, and a separate tactical channel to be used during the incident. When a tactical-level management unit is 


\section{Career Fire Lieutenant Dies in Cluttered Apartment Fire on 19th Floor of High-rise Residential Building - New York}

implemented (division or group), a fire department should provide a dispatch channel, a command channel, and a tactical channel. A fire department should provide the necessary number of radio channels with multiple tactical channels, depending on the type of incident and the complexity of the incident.

Effective fireground and incident scene communications are also essential to the success of the personnel accountability system. The function of resource accountability should be assigned to a member such as a chief's aide who is responsible for maintaining the location and status of all assigned resources at an incident. This is separate from the role of the incident commander. The incident commander is responsible for the overall command and control of the incident. Due to the importance of responder safety, this function should be assigned to an accountability officer or resource status officer. A number of members could function in this role including a staff assistant, chief officer, apparatus driver/operator, or other responder. There are many means of accounting for resources. Components can include tactical worksheets, command boards, apparatus riding lists, company responder boards, electronic bar-coding systems, and so forth depending on whether equipment or personnel are being tracked. These components can be used in conjunction with one another to facilitate the tracking of responders by both location and function. The components of any resource accountability system should be modular and expand with the size and complexity of the incident [NFPA 2014].

An incident commander cannot successfully manage all of these functions without the benefit of a tactical worksheet, personnel accountability system, and adequate communications. The intent of command safety is to provide the incident commander with a system that allows the systematic development of an incident and in an environment without distractions. Also, managing all these systems can quickly become overwhelming and create task saturation for the incident commander. A staff assistant or chief's aide is another essential element of this process.

At this incident, command moved between the main lobby and the outside of the high-rise apartment building. A tactical worksheet was used late in the incident. Fireground communications were generally effective, however three Mayday transmissions from the Ladder 119 lieutenant were not heard by most everyone on the fireground. Also, verbal communications rescinding the Mayday by the Engine 211 lieutenant were not relayed to incident command.

\section{Recommendation \#10: Fire departments should ensure that existing standard operating procedures for high-rise firefighting operations are reviewed, revised as necessary and implemented.}

Discussion: Although there is no clear evidence that this recommendation would have prevented this fatality, the recommendation is presented as good fireground safety practice. The difference between a successful emergency operation that is brought to an early conclusion and one that becomes a prolonged effort, often heavily taxing a department's resources, depends greatly on actions taken by first-arriving companies. Experience has shown that at a high-rise emergency incident, initial actions must fall into a priority order if the operation is to progress smoothly to a successful conclusion. A high-rise fire takes a considerable commitment of staffing and resources and differs greatly from 


\section{Career Fire Lieutenant Dies in Cluttered Apartment Fire on 19th Floor of High-rise Residential Building - New York}

residential or other commercial structure fires. Most importantly, the incident management system structure must be developed from the bottom up, initiated by the first-arriving officer [USFA 1996].

Standard operating procedures (SOPs) play an integral role in establishing order and consistency in operations at any emergency scene. They are especially important in high-rise incidents because of the inherent complexities of fighting a high-rise fire. SOPs should be written to achieve these purposes:

- Establish a high-rise strategic and tactical organization that fits the needs of the department and most importantly the needs of the incident.

- Establish levels of response (i.e., number of units assigned on each alarm).

- Establish roles and responsibilities of arriving companies by alarm (e.g., first alarm - fire attack, staging, lobby control, and base to assure overall management and resource accountability prior to the second alarm) and the company officers.

- Establish a system of fire-fighting operations familiar to all members of the organization. [USFA 1996]

Additionally, an SOP provides the framework of a fire department's response to a high-rise incident plus the special challenges that are presented and the strategies and tactics that should be employed to perform safely and effectively in a high-rise environment. An SOP establishes a degree of order to an emergency scene, which by nature is usually chaotic and very hectic. Basic topics to cover in a highrise SOP are listed below, which is not an all-inclusive list:

- Level of response (i.e., number and type of apparatus dispatched)

- Deployment of resources upon arrival (1st, 2nd, 3rd, 4th due (fire attack, staging, lobby control, and base need to be established))

- Establishment and structure of the incident management system (develop an SOP for the deployment of chief officers upon arrival)

- Personnel accountability system

- Fire fighter safety

- Lobby control

- Use of elevators and stairwells

- Evacuation and rescue

- Water supply

- Supplementing and supporting fire protection systems

- Proper hose and nozzles for interior operations

- Ventilation

- Contingency plans for failure of fire protection systems [Los Angeles Fire Department 2007, National Incident Management System Consortium 2008].

In this incident, the fire department did have detailed standard operating procedures for multiple dwelling fires and high-rise structures. These standard operating procedures are available to all fire department members. 


\section{Career Fire Lieutenant Dies in Cluttered Apartment Fire on 19th Floor of High-rise Residential Building - New York}

\section{Recommendation \#11 Municipalities, building owners, and authorities having jurisdiction should consider requiring sprinkler systems to be installed in multi-family and residential mixed-occupancy structures.}

Discussion: Fire development beyond the incipient stage is one of the greatest hazards that fire fighters are exposed to. This exposure and risk to fire fighters can be dramatically reduced when fires are controlled or extinguished by automatic sprinkler systems. NFPA statistics show that most fires in sprinklered buildings are controlled prior to fire department arrival by the activation of one or two sprinkler heads [Hall 2013]. The presence of automatic fire sprinklers also reduces the exposure risk to fire fighters in rescue situations by allowing the safe egress of building occupants before the fire department arrives on scene. Finally, by controlling fire development, the exposure to hazards such as building collapse and overhaul operations are greatly reduced, if not eliminated.

The 21-story residential apartment building involved in this incident was not equipped with an automatic sprinkler system. The presence and activation of an automatic sprinkler system could have extinguished the fire or limited fire growth and possibly extinguishing the fire before emergency responders arrived. Extinguishing or limiting fire growth can significantly reduce the risk to fire fighters and emergency responders.

Recommendation \#12: First responder radio manufacturers, research/design facilities and standard setting bodies should continue research and efforts to improve radio system capabilities.

Discussion: Several NIOSH Fire Fighter Fatality Investigation Reports have cited issues with portable radio communication, and the International Association of Fire Chiefs has released an interim report concerning possible communications problems involving digital two-way portable radios in close proximity to common fireground noise [IAFC 2008].

To facilitate communication, equipment manufacturers have designed facepiece-integrated microphones, intercom systems, throat mikes, and bone mikes worn in the ear or on the forehead [USFA/FEMA 1999, Tridata 2003]. The National Institute for Standards and Technology (NIST) has tested portable radios in simulated fire fighting environments and has identified that radios are vulnerable to exposures to elevated temperatures. Some degradation of radio performance was measured at elevated temperatures ranging from 100 to 260 degree $\mathrm{C}$, with the radios returning to normal function after cooling down. Additional research is needed in this area [Davis, Donnelly and Selepak 2006, NIST 2007].

As a result of the above mentioned incidents and testing, the NFPA has formed a technical committee to develop a new standard to help address these fireground issues. This new standard is title "NFPA 1802: Standard on Two-Way, Portable RF Communication Devices for Use by Emergency Services Personnel in the Hazard Zone.” It is anticipated to be released during the 2018 cycle. 


\section{Career Fire Lieutenant Dies in Cluttered Apartment Fire on 19th Floor of High-rise Residential Building - New York}

In this incident, a number of confirmed radio transmissions were not heard by most everyone on the fireground including Mayday transmissions called by the Ladder 119 lieutenant. The fire department uses a "Handie Talkie Recorder System” set up in every Battalion car to capture fireground radio transmissions made at the scene. This system recorded the L-119 officer's MAYDAYS and other messages that were not heard by most fire fighters on the fireground.

\section{References}

Ciarrocca M, Harms T [2011]. Help on the scene. Fire Rescue Magazine 29(2):40-48.

Davis WD, Donnelly MK, Selepak MJ [2006]. Testing of portable radios in a fire fighting environment. Gaithersburg, MD: National Institute of Standards and Technology, Building and Fire Research Laboratory, NIST Technical Note 1477.

Dunn V. [1992]. Safety and survival on the fireground. Saddle Brook, NJ: Fire Engineering Books and Videos.

FDNY [2015]. Citywide statistics. New York, NY: New York City Fire Department, http://www.nyc.gov/html/fdny/html/stats/citywide.shtml.

Gagliano M, Phillips C, Jose P, Bernocco S [2008]. Air management for the fire service. Tulsa, OK: Penn Well Corporation, Fire Engineering.

Hall J Jr. [2013]. U.S. experience with sprinklers. Quincy, MA: National Fire Protection Association, Fire Analysis and Research Division, http://www.nfpa.org/research/reports-and-statistics/fire-safetyequipment/us-experience-with-sprinklers.

IAFC [2008]. International Association of Fire Chiefs. Interim Report and Recommendations: Fireground Noise and Digital Radio Transmissions http://www.iafc.org/associations/4685/files/digProj_DPWGinterimReport.pdf, Accessed April 2016.

IAFC [2012]. Rules of engagement for structural firefighting. Fairfax VA: International Association of Fire Chiefs, Safety, Health and Survival Section, http://websites.firecompanies.com/iafcsafety/files/2013/10/Rules_of_Engagement_short_v10_2.12.pdf

IAFC [2015]. Near miss report of the week: the dangers of moving through a hoarder house. Fairfax, VA: International Association of Fire Chiefs, August 15.

IAFF [2012]. IAFF Fire Ground Survival Program. Washington, DC: International Association of Fire Fighters. http://www.iaff.org/HS/FGS/FGSIndex.htm. Date accessed: April 2016.

LAFD [2006]. Los Angeles Fire Department Lesson Plan 407; Los Angeles, CA: Los Angeles Fire Department. 


\section{Career Fire Lieutenant Dies in Cluttered Apartment Fire on 19th Floor of High-rise Residential Building - New York}

LAFD [2007]. Los Angeles Fire Department high-rise manual. Los Angeles, CA: Los Angeles Fire Department.

LAFD [2011]. Los Angeles Fire Department Command post training. Los Angeles, CA: Los Angeles Fire Department.

LAFD [2016]. Los Angeles Fire Department Training Bulletin \# 074- Search and Rescue Procedures utilizing one inch hose lines. Los Angeles, CA: Los Angeles Fire Department.

National Incident Management System Consortium [2008]. Incident Command System (ICS) model procedures guide for incidents involving structural fire fighting, high-rise, multi-casualty, highway, and managing large-scale incidents using NIMS ICS, Book 1. Stillwater, OH: Fire Protection Publications, Oklahoma State University.

NIST [2007]. Advanced fire service technologies program. Proceedings of the 2007 NIST Annual Fire Conference. Gaithersburg, MD: National Institute of Standards and Technology, Building and Fire Research Laboratory.

NFPA [2013a]. NFPA 1001 Standard for fire fighter professional qualifications. 2013 edition. Quincy, MA: National Fire Protection Association.

NFPA [2013b]. NFPA 1404 Standard for fire service respiratory protection training. 2013 edition. Quincy, MA: National Fire Protection Association.

NFPA [2013c]. NFPA 1500 Standard on fire department occupational safety and health program. 2013 edition. Quincy, MA: National Fire Protection Association.

NFPA [2013d]. NFPA 1852 Standard on Selection, Care, and Maintenance of Open-Circuit Self-Contained Breathing Apparatus (SCBA). 2013 edition. Quincy, MA: National Fire Protection Association.

NFPA [2013e]. NFPA 1981 Standard on open-circuit self-contained breathing apparatus for emergency services. 2013 edition. Quincy, MA: National Fire Protection Association.

NFPA [2014]. NFPA 1561 Standard on emergency services incident management system and command safety. 2014 edition. Quincy, MA: National Fire Protection Association.

NFPA [2015]. NFPA 1250 Recommended Practice in Fire and Emergency Service Organization Risk Management. 2015 edition. Quincy, MA: National Fire Protection Association.

NIOSH [2009]. Nine career fire fighters die in rapid fire progression at commercial furniture showroom - South Carolina. Morgantown, WV: U.S. Department of Health and Human Services, 


\section{Career Fire Lieutenant Dies in Cluttered Apartment Fire on 19th Floor of High-rise Residential Building - New York}

Centers for Disease Control and Prevention, National Institute for Occupational Safety and Health, F2007-18, http://www.cdc.gov/niosh/fire/pdfs/face200718.pdf.

NIOSH [2010]. NIOSH ALERT: Preventing Deaths and Injuries of Fire Fighters using Risk Management Principles at Structure Fires. July 2010. Cincinnati, OH: U.S. Department of Health and Human Services, Public Health Service, Centers for Disease Control and Prevention, National Institute for Occupational Safety and Health (NIOSH), Publication No. 2010-153.

http://www.cdc.gov/niosh/docs/2010-153/.

NIOSH [2011]. Career fire fighter dies while conducting a search in a residential house fire - Kansas. Morgantown, WV: U.S. Department of Health and Human Services, Centers for Disease Control and Prevention, National Institute for Occupational Safety and Health, F2010-13 http://www.cdc.gov/niosh/fire/reports/face201013.html.

NIOSH [2012]. Volunteer fire fighter caught in a rapid fire event during unprotected search, dies after facepiece lens melts-Maryland. Morgantown, WV: U.S. Department of Health and Human Services, Centers for Disease Control and Prevention, National Institute for Occupational Safety and Health, F2011-02, http://www.cdc.gov/niosh/fire/pdfs/face201102.pdf.

NIOSH [2013]. Career captain sustains injuries at a 21/2 story apartment fire then dies at hospitalIllinois. Morgantown, WV: U.S. Department of Health and Human Services, Centers for Disease Control and Prevention, National Institute for Occupational Safety and Health, F2012-28, http://www.cdc.gov/niosh/fire/pdfs/face201228.pdf.

NIST, UL [2013]. Studying fire behavior and fireground tactics. Presentation at the IAFF Redmond Symposium, Denver, CO, August 24.

OSHA [1998]. 29 CFR Parts 1910 and 1926 Respiratory Protection; Final Rule. Federal Register Notice 1218-AA05. Vol. 63, No. 5. January 8, 1998. U.S. Department of Labor, Occupational Safety and Health Administration. Washington DC.

Peterson JA and Merinar TR [1997]. Respirator Maintenance Program Recommendations for the Fire Service. Journal of the International Society for Respiratory Protection. Vol 15, Issues III \& IV. Fall/Winter 1997.

Phoenix Fire Dept., M.P. 202.03 Basic Self Survival Responsibilities

USFA [1996]. Special report: operational considerations for high-rise firefighting. Emmitsburg, MD: Federal Emergency Management Agency, United States Fire Administration, http://www.usfa.fema.gov/downloads/pdf/publications/tr-082.pdf.

USFA/FEMA [1999]. Improving firefighter communications. Emmitsburg, MD: United States Fire Administration, USFA-TR-099 


\section{Career Fire Lieutenant Dies in Cluttered Apartment Fire on 19th Floor of High-rise Residential Building - New York}

TriData Corporation [2003]. Current status, knowledge gaps, and research needs pertaining to fire fighter radio communication systems(http://www.cdc.gov/niosh/fire/RadComSy.html) (http://www.cdc.gov/niosh/fire/RadComSy.html) Arlington, VA: TriData Corporation. Report prepared for NIOSH. Date accessed April 2016.

Weather Underground [2014]. Weather history for KNYC, July 5. Atlanta, GA: The Weather Channel Interactive, Inc., http://www.wunderground.com/history/airport/KNYC/2014/7/5/DailyHistory.html?req_city=Brooklyn \&req_state=NY\&req_statename=\&reqdb.zip=11216\&reqdb.magic=1\&reqdb.wmo=99999.

\section{Investigator Information}

This incident was investigated by Timothy Merinar, Safety Engineer, and Murrey Loflin, Investigator, with the Fire Fighter Fatality Investigation and Prevention Program, Surveillance and Field Investigations Branch, Division of Safety Research, NIOSH located in Morgantown, WV. An expert technical review was provided by Robert D. Neamy, Retired Deputy Chief/Operations, Los Angeles Fire Department. A technical review was also provided by the National Fire Protection Association, Public Fire Protection Division.

\section{Additional Information}

\section{Modern Fire Behavior}

This website is meant to serve as a clearinghouse of news and training information related to Modern Fire Behavior and Modern Building Construction Research, Tactics, and Practices along with actual street experiences. http://modernfirebehavior.com/. ModernFireBehavior.com is a joint effort between www.FirefighterCloseCalls.com and the Underwriters Laboratories Fire Safety Research Institute.

\section{IAFC Rules of Engagement for Firefighter Survival}

The international Association of Fire Chiefs (IAFC) is committed to reducing fire fighter fatalities and injuries. As part of that effort, the nearly 1,000 member IAFC Safety, Health and Survival Section has developed the DRAFT "Rules of Engagement for Structural Firefighting” to provide guidance to individual fire fighters and incident commanders, regarding risk and safety issues when operating on the fireground. The intent is to provide a set of "modern procedures" for structural firefighting to be made available by the IAFC to fire departments as a guide for their own standard operating procedure development process. http://www.iafcsafety.org/downloads/Rules_of_Engagement.

\section{IAFF Fire Ground Survival Program}

The purpose of the International Association of Fire Fighters (IAFF) Fire Ground Survival Program is to ensure that training for Mayday prevention and Mayday operations are consistent between all fire fighters, company officers and chief officers. Fire fighters must be trained to perform potentially lifesaving actions if they become lost, disoriented, injured, low on air or trapped. Funded by the IAFF and assisted by a grant from the U.S. Department of Homeland Security through the Assistance to 
Career Fire Lieutenant Dies in Cluttered Apartment Fire on 19th Floor of High-rise Residential Building - New York

Firefighters (FIRE Act) grant program, this comprehensive fire ground survival training program applies the lessons learned from fire fighter fatality investigations conducted by the National Institute for Occupational Safety and Health (NIOSH) and has been developed by a committee of subject matter experts from the IAFF, the International Association of Fire Chiefs (IAFC) and NIOSH.

http://www.iaff.org/HS/FGS/FGSIndex.htm.

National Institute for Standards and Technology (NIST) - Fire on the Web

Fire on the Web is a collection of resources from the Building and Fire Research Laboratory's Fire Research Division at NIST. These Web pages provide links to fire related software, experimental fire data and mpeg/quick time videos of fire tests that can be downloaded and/or viewed with a Web browser. http://www.nist.gov/el/fire_research/firesafety/fireontheweb.cfm.

\title{
Underwriters Laboratories (UL) Firefighter Safety Research Institute
}

An online course offered by the UL Firefighter Safety Research Institute (FSRI) highlights the tactical application of nearly two decades of research at the National Institute of Standards and Technology (NIST) and UL on how best to fight modern fires. The New York City Fire Department (FDNY), NIST and UL FSRI set fire to abandoned townhouses on Governors Island, New York, in a series of experiments to examine tactics for controlling fires and rescuing occupants inside burning homes in 2012.

http://www.firecompanies.com/modernfirebehavior/governors\%20island\%20online\%20course/story.ht $\underline{\mathrm{ml}}$

NIOSH LODD investigation involving hoarding The NIOSH Fire Fighter Fatality Investigation and Prevention Program has investigated a number of incidents in which hoarding and clutter within the fire structure made fire fighting operations difficult and contributed to a number of fatalities and injuries. Please see the following NIOSH investigation reports for additional information on the hazards of hoarding fires:

\author{
Volunteer Fire Fighter Found Unresponsive With His Facepiece Off Dies Eight Days \\ Later - Maryland \\ http://www.cdc.gov/niosh/fire/pdfs/face201313.pdf
}

Career Fire Fighter Dies When Trapped by Collapsed Canopy during a Two Alarm Attached Garage Fire - Pennsylvania http://www.cdc.gov/niosh/fire/reports/face200708.html
Career Lieutenant Dies in Residential Structure Fire - Colorado http://www.cdc.gov/niosh/fire/reports/face200619.html

One Career Fire Fighter Dies and a Captain Is Hospitalized After Floor Collapses in Residential Fire - North Carolina http://www.cdc.gov/niosh/fire/reports/face200211.html 
Career Fire Lieutenant Dies in Cluttered Apartment Fire on 19th Floor of High-rise Residential Building - New York

Residential House Fire Claims the Life of One Career Fire Fighter - Florida http://www.cdc.gov/niosh/fire/pdfs/face200044.pdf

\section{Disclaimer}

Mention of any company or product does not constitute endorsement by the National Institute for Occupational Safety and Health (NIOSH). In addition, citations to websites external to NIOSH do not constitute NIOSH endorsement of the sponsoring organizations or their programs or products. Furthermore, NIOSH is not responsible for the content of these websites. All web addresses referenced in this document were accessible as of the publication date. 
Career Fire Lieutenant Dies in Cluttered Apartment Fire on 19th Floor of High-rise Residential Building - New York

\section{Appendix One}

Personal Protective Equipment Evaluation 
Career Fire Lieutenant Dies in Cluttered Apartment Fire on 19th Floor of High-rise Residential Building - New York

\section{NIOSH, National Personal Protective Technology Laboratory (NPPTL) \\ SCBA Evaluation Report (Summary) \\ NIOSH Reference: TN-19836}

The National Institute for Occupational Safety and Health (NIOSH) has concluded its investigation conducted under NIOSH Task Number TN-19836. This investigation consisted of the inspection of a Scott Health and Safety AirPak 4.5, 45 minute, 4500 psig, Self-Contained Breathing Apparatus (SCBA). The SCBA unit in question was contained inside an individual cardboard shipping box and was delivered to the NIOSH facility in Bruceton, Pennsylvania, on September 29, 2014. The package was taken to the NPPTL, Technology Evaluation Branch (TEB) Respirator Equipment Storage Area (building 20) and stored under lock until the time of the examination and evaluation.

\section{SCBA Inspection:}

An initial general inspection of the SCBA unit was conducted on October 9, 2014. The unit was identified as the Scott Health and Safety AirPak 4.5 model. In addition, Scott Health and Safety performed a down loading of the data logger present on the SCBA with NIOSH personnel present on November 25, 2014.

A complete visual inspection of the SCBA unit was conducted on October 9, 2014. The unit was examined, component by component in the condition received, to determine conformance to the NIOSH-approved configuration. The visual inspection process was photographed.

The complete SCBA inspection is summarized in Appendix I of the enclosed Status Investigation Report. The condition of each major component was photographed with a digital camera. Images of the SCBA unit are contained in the Appendix III of the report.

The SCBA unit in question, Unit \#1, suffered some heat damage, but exhibited other signs of wear and tear; and the unit was covered lightly with general dirt and grime. The remote gauge was damaged and unreadable. The cylinder valve as received on the unit was in the closed position. The cylinder gauge could not be read as assembled to the backframe. There was 0 psig remaining in the cylinder.

The cylinder valve hand-wheels could be turned. The regulator mating and sealing area on the unit was clean. Pictures of the SCBA facepiece were supplied by NIOSH/DSR. Unit \#1 appeared to have extensive damage to the facepiece lens and visibility through the lens appeared to be poor.

The PASS device on the Unit \#1 functioned. The NFPA approval label on Unit \#1 was present and readable.

\section{Personal Alert Safety System (PASS) Device}

The Personal Alert Safety System (PASS) device on Unit \#1 was operable and functional. The PASS device was activated and appeared to function normally. However, the unit was not tested against the 
Career Fire Lieutenant Dies in Cluttered Apartment Fire on 19th Floor of High-rise Residential Building - New York

specific performance requirements of NFPA 1982, Standard on Personal Alert Safety Systems, (PASS), 1998 Edition. Because NIOSH does not certify PASS devices, no further evaluation was performed.

\section{SCBA Compressed Air Cylinder Contents}

During the inspection, it was noted that the compressed air cylinder of the unit was empty. No air sample was collected for analysis.

\section{$\underline{\text { SCBA Testing }}$}

The purpose of the testing was to determine the SCBA conformance to the approval performance requirements of Title 42, Code of Federal Regulations, Part 84 (42 CFR 84). Further testing was conducted to provide an indication of the SCBA conformance to the National Fire Protection Association (NFPA) Air Flow Performance requirements of NFPA 1981, Standard on Open-Circuit Self-Contained Breathing Apparatus for the Fire Service, 1997 Edition.

NIOSH SCBA Certification Tests (in accordance with the performance requirements of 42 CFR 84):

1. Positive Pressure Test [§ 84.70(a)(2)(ii)]

2. Rated Service Time Test (duration) [§ 84.95]

3. Static Pressure Test [§ 84.91(d)]

4. Gas Flow Test [§ 84.93]

5. Exhalation Resistance Test [§ 84.91(c)]

6. Remaining Service Life Indicator Test (low-air alarm) [§ 84.83(f)]

\section{National Fire Protection Association (NFPA) Tests (in accordance with NFPA 1981, 1997 Edition):}

\section{Air Flow Performance Test [Chapter 5, 5-1.1]}

After an initial pressure check test, testing of the unit was conducted on December 12, 2014. The SCBA Unit \#1 did not meet all the testing requirements. The unit end of service time alarm sounded intermittently during the service life test indicating an issue with the pressure reducer.

Appendix II of the Status Investigation Report contains complete NIOSH and NFPA test reports for the SCBA Unit \#1. Tables One and Two summarize the NIOSH and NFPA test results.

\section{Summary and Conclusions}

One SCBA unit was submitted to NIOSH by the NIOSH Division of Safety Research for the Fire Department of New York for evaluation on September 29, 2014. The SCBA was initially inspected on October 9, 2013. The unit was identified as a Scott Health and Safety AirPak 4.5, 45 minute, 4500 
Career Fire Lieutenant Dies in Cluttered Apartment Fire on 19th Floor of High-rise Residential Building - New York

psig SCBA (NIOSH approval number, TC-13F-0212CBRN). In addition, the SCBA data logger was down loaded by representatives of Scott Health and Safety on November 25, 2014 with NIOSH personnel present. An in-depth inspection of the SCBA was conducted on October 9, 2014. The unit was in mostly fair condition with the unit having various levels of damage to the regulator, remote gauge and cylinder. The cylinder for Unit \#1 was determined to be within specification. This cylinder is required to be recertified every 5 years.

The integrated PASS unit on Unit \#1 was activated and appeared to function normally.

No air remained in the cylinder so no air sample was taken and analyzed.

The SCBA Unit \#1 was tested on December 12, 2014, utilizing a replacement cylinder and facepiece that were supplied by the Fire Department of New York. The Unit \#1 did not meet all the requirements as tested. The unit end of service time alarm sounded intermittently indicating an issue with the pressure reducer.

After the inspections and testing of the SCBA unit, the respirator was placed back into storage pending the final disposition from the Fire Department of New York.

If this SCBA unit is to be placed back into service, then the unit should be repaired extensively, cleaned, the cylinder replaced, and any other damaged components replaced and tested by a qualified SCBA technician.

The complete NIOSH NPPTL SCBA evaluation report for TN- 19836 is available upon request. 